\title{
Guild structure and foraging impact of blue crabs and epibenthic fish in a subestuary of Chesapeake Bay
}

\author{
Anson H. Hines, A. Mark Haddon, Lenore A. Wiechert \\ Smithsonian Environmental Research Center, PO Box 28, Edgewater, Maryland 21037, USA
}

\begin{abstract}
Structure and impact of the guild of epibenthic predators foraging on infaunal communities were measured in the Rhode River, a small mesohaline subestuary of Chesapeake Bay. Measures of long-term variation in guild structure (species composition, abundance, and size), patterns of prey utilization (stomach contents), and predator exclusion experiments assessed the interaction of guild structure and function. Monthly otter trawls from 1981 to 1988 caught 38 species, which utilized the subestuary on a markedly seasonal cycle with peak abundances during summer months. Species composition was significantly consistent among years, with the blue crab Callinectes sapidus, a sciaenid fish Leiostomus xanthurus or, in one year, Micropogonias undulatus, and the sole Trinectes maculatus comprising the dominant members of the guild. However, abundances of all 4 dominant species fluctuated significantly among years and, except for $M$. undulatus, among stations. Seasonally consistent patterns of population size structure showed that: $L$. xanthurus was composed of only 1 yearclass recruiting in May; $M$. undulatus had 1 year-class with recruitment in November; $T$. maculatus was composed of 3 year-classes with recruitment in October; and C. sapidus had a 2 year-class population with recruitment in late fall and spring. Despite marked juvenile growth over the season, ontogenetic changes in diets of the 4 species occur at sizes smaller than those comprising the populations. All predators consumed a diversity of infaunal prey early in the summer, but their diets varied significantly during the season as prey availability changed. $L$. xanthurus and $T$. maculatus consumed mainly amphipods and polychaetes early in the season, and took increasing frequencies of clam siphons later; while $M$. undulatus primarily consumed amphipods. C. sapidus consumed mainly whole clams, other blue crabs and fish, but shifted from amphipods early in the season to increased frequencies of clams late in the season. Dietary breadth and overlap within the guild reflected the generalized, overlapping diets of the 4 species, although dietary breadth varied with predator species and season. For all species stomach contents did not vary with sediment type. Natural densities of Macoma balthica, a major dietary component for C. sapidus, responded to annual fluctuations in crab abundance as well as to variation in clam recruitment. Experimental exclusion of predators from clams ( $M$. balthica) placed in buckets in the subestuary significantly increased clam survival. Experimental exclusion of epibenthic predators at 5 stations in the subestuary resulted in significantly higher densities for 12 of 16 infaunal species as well as for total infaunal organisms and higher ratios of infaunal predators to prey. However, most infaunal species exhibited significant variation among stations, reflecting spatial variation in both predation intensity and prey abundances. Experimental exclusion of the epibenthic predators from plots of dyed sand showed that the guild caused major sedimentary disturbance to sediment depths of $10 \mathrm{~cm}$, while low infaunal densities of subsurface deposit feeders caused comparatively little bioturbation. These experiments indicate that the guild's foraging activity not only has strong direct effects. on infaunal community structure, but that the guild also has significant indirect effects on infaunal community organization and patch dynamics which are highly variable in space and time.
\end{abstract}

\section{INTRODUCTION}

Predation by epibenthic fish and crabs can regulate the abundance and species composition of infauna in marine and estuarine soft-bottom communities (Virnstein 1977, 1979, Peterson 1979, Holland et al. 1980, Dayton 1984, Quammen 1984). As a group of phylogenetically and morphologically dissimilar species utilizing overlapping benthic resources, these predatory fish and crabs can be viewed properly as a guild (sensu Root 1967). In many shallow temperate ecosystems, particularly in estuaries, the abundance and species composition of epibenthic predatory guilds fluctuate dramatically on a seasonal cycle and among years (Holland et al. 1980, Livingston 1984, Jeffries \& Terceiro 1985, Hines et al. 1987a, b, Horwitz 1987). 
Species composition and abundance of predatory guilds in marine communities also often vary in space along regional gradients of latitude, salinity, wave exposure, and other factors (Menge and Sutherland 1976, Boesch 1977, Menge 1978a, b, Bertness et al. 1981, Menge and Lubchenko 1981, Heck and Wilson 1987), and even on localized spatial scales (Hines et al. 1987a). In soft-bottom communities, no single species dominates a predatory guild in a functional sense (i.e. as a keystone predator, sensu Paine 1966) (Peterson 1979, Levinton 1982). Analyses of stomach contents indicate that component species of many guilds are dietary generalists with broadly overlapping but significantly different diets (Livingston 1984). Moreover, component species vary considerably in modes of locomotion, burrowing, and prey capture, which cause significant disturbance to sediments (Woodin 1981, 1983, Van Blaricom 1982, Thayer 1983). Thus, the impact of a guild's predation on, and disturbance of, infaunal communities probably varies qualitatively as well as quantitatively in space and time with fluctuations in its species composition and abundance.

In Chesapeake Bay, the blue crab Callinectes sapidus and several species of sciaenid and flat fish comprise the dominant members of the guild of epibenthic predators foraging on infaunal invertebrates (Hines et al. 1987a, Horwitz 1987). The guild is active in warm summer months, while in winter the component species either depart from much of the estuary or become inactive. Experimental exclusion of this guild from the benthos in the lower and central portions of Chesapeake Bay demonstrated that infaunal abundance and species composition are drastically restricted by the guild's predatory activity (Virnstein 1977, 1979, Holland et al. 1980). However, there have been no experimental manipulations of predator impact in lower salinity zones, where infaunal diversity is low from the outset, and thus may show limited response of species composition to variation in predation pressure. Although the diets of most of the component species have been analyzed (Chao \& Musick 1977. Laughlin 1982, Livingston 1984, Horwitz 1987, Smith \& Coull 1987), there has been little attempt to assess the extent and seasonal variation of the guild's partitioning of the prey resource. Little attention has been paid to the effects of spatial variation of the predatory guild on infaunal communities on a local scale of hundreds to thousands of meters. There also has been little quantitative assessment of the relative importance of the epibenthic guild in disturbing estuarine sediments compared to bioturbation by infauna (Rhoads \& Young 1971, Young 1971, Rhoads 1974, Brenchley 1981, Thayer 1983, Woodin 1983, Posey 1987).

The purpose of this paper is to analyze the structure and impact of the guild of epibenthic predators forag- ing on macro-infauna in a small subestuary of the lower mesohaline zone in Chesapeake Bay. We utilize the guild concept to describe patterns of resource utilization by the predators, so that we can determine the major impacts of the guild upon those resources. We take the approach that guild structure and function in the community are integrally linked, requiring analysis of guild dynamics for a better understanding of the guild's predatory impact. Because our focus is on guild function and impact, we do not assess competitive interactions among guild members, as is sometimes inferred from patterns of resource partitioning (Cody 1974). Rather, in describing guild structure we focus on several major variables that can affect a guild's utilization of resources: temporal and spatial variation in abundance and species composition, temporal variation in size structure, and temporal and spatial variation in utilization of food resources. To test the major effects of guild foraging activity upon benthic community structure, we conducted predator exclusion experiments focusing on spatial variation in infaunal responses to altered predation pressure and on bioturbation. Instead of restricting our sampling to short periods of time and our experiments to designs unreplicated in space, we utilized a combination of mensurative and experimental approaches intended to reveal more accurately and realistically several major aspects of seasonal, annual, spatial, and functional variability characterizing predator-prey interactions of the guild in this ecosystem.

\section{METHODS}

Study site. This study was conducted from 1981 to 1988 in the Rhode River $\left(38^{\circ} 51^{\prime} \mathrm{N}, 76^{\circ} 32^{\prime} \mathrm{W}\right)$, a 485 ha subestuary of the lower mesohaline zone of Chesapeake Bay (Fig. 1). Aspects of the water quality, species composition, and population dynamics of infaunal invertebrates and fish in the subestuary have been described (Correll 1978, Cory \& Dresler 1981, Hines \& Comtois 1985, Hines et al. 1987a, b). The subestuary is shallow (maximum depth $=4 \mathrm{~m}$ ), with about $80 \%$ of the bottom area composed of fine silt and clay and $20 \%$ composed of fine to medium sand. Monthly mean water temperatures exhibited an annual cycle with a peak of 28 to $29^{\circ} \mathrm{C}$ in July and a low of 2 to $4{ }^{\circ} \mathrm{C}$ in January. A thermocline did not develop, and the water column was generally well-mixed, except during calm summer days when a continuous 1 to $2{ }^{\circ} \mathrm{C}$ gradient developed from surface to bottom as surface water heated. Supersaturated oxygen concentrations occurred frequently during midday in summer, but the water column occasionally exhibited hypoxic conditions ( 1 to $2 \mathrm{mg} \mathrm{l}^{-1}$ dissolved $\mathrm{O}_{2}$ ) lasting å few hours 


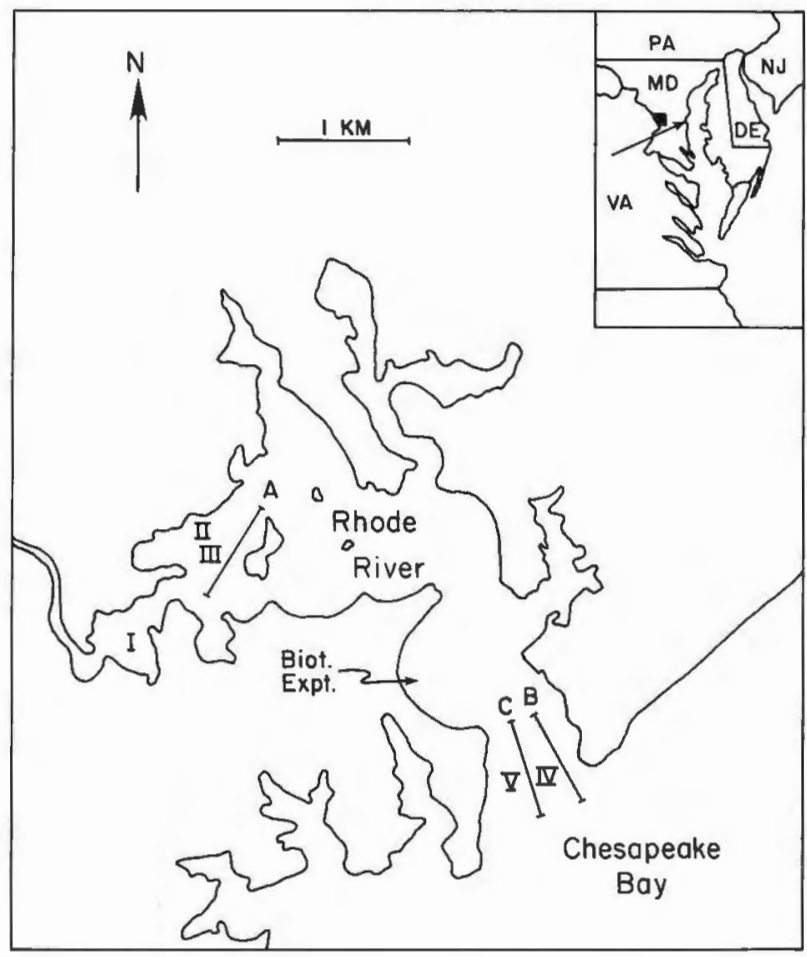

Fig. 1. Map of Rhode River subestuary showing location of study site on Chesapeake Bay (inset) and sampling stations. Lines show location of otter trawl stations on muddy (A and B) and sandy (C) sediments. Roman numerals indicate locations of predator exclusion experiments on muddy (I, III and IV) and sandy (II and V) sediments. Location of the bioturbation experiment (Biot. Expt.) is also indicated

during early summer mornings. Salinity cycled seasonally with monthly mean low salinities of 4 to $6 \%$ in May increasing gradually in summer and fall to monthly mean high salinities of 11 to $17 \%$. Salinities during the study period of the 1980 's were significantly higher than during the 1970's as a result of prolonged periods of drought (Hines et al. 1987a).

Species composition and abundance of epibenthic fish and crabs. Species composition and abundances of epibenthic fish and crabs were estimated monthly from April to December over the $8 \mathrm{yr}$ period from August 1981 to December 1988 with otter trawls; winter samples (January to March) were not taken because predators were nearly absent then (Hines et al. $1987 \mathrm{a}, \mathrm{b}$ ). The trawl net had a 3-m-wide mouth, 5-cm mesh net body, 7-mm mesh cod end liner, and a tickler chain. Trawls were pulled for a fixed distance of $900 \mathrm{~m}$ on 3 consecutive days at 3 stations: 1 at the head of the river over the mud bottom and 2 at the river mouth over mud and sand bottoms, respectively (Fig. 1). For each trawl, all organisms caught were identified to species and counted, and body sizes (total body length of fish, maximal carapace width of blue crabs) of a subset of 20 to 40 haphazardly selected individuals of each species were measured to the nearest $\mathrm{mm}$. When fewer than 20 individuals of a species were caught, all were measured.

Annual variation in species composition was tested by Friedman's randomized block method (Sokal \& Rohlf 1981), in which significant $\chi^{2}$ values indicated consistent species rankings among years and, thus, non-significant changes in species relative abundance. Differences in species abundance among stations and years in the trawl data were tested by ANCOVA (analysis of covariance) to remove effects of seasonal cycles in abundance following the methods of Holland (1985) and Hines et al. (1987a). All data on species abundances were $\log _{10}$ transformed before analysis and $F_{\max }$ tests (Sokal \& Rohlf 1981) indicated homogeneity of variances after transformations. The effects of year, station, and year $\times$ station interaction on population abundance were tested after partitioning seasonal cycles in abundance using trigonometric functions $\sin (\mathrm{ct})$ and $\cos (\mathrm{ct})$ as covariates, where $\mathrm{c}=$ $2(3.14 / 12)$ as the constant for converting time in months to radians and $t=$ the number of the month of the sample.

Diet. Stomach contents of blue crab Callinectes sapidus, spot Leiostomus xanthurus, croaker Micropogonias undulatus, and hogchoker Trinectes maculatus were analyzed using the following procedure similar to Hines (1982). During 1982 and 1983, samples of each species were selected haphazardly from trawls at the sand and mud stations at the river mouth in June when infaunal prey abundances were high, and again in September following the summer season of intense predation. Sample sizes are reported in Appendix 1. Within each species, individuals of approximately the same size that were large enough to feed predominantly on macro-infauna were selected to minimize potential effects of ontogenetic changes in diet within samples and between months of the season (e.g. Laughlin 1982, Smith \& Coull 1987). These samples were placed on ice within $5 \mathrm{~min}$ of collection to prevent continued digestion of stomach contents before dissection within $1 \mathrm{~h}$. For each individual, body size (carapace width or total fish length) was measured to the nearest $\mathrm{mm}$, and the foregut was removed, fixed in $10 \%$ formaldehyde, and stored separately in $70 \%$ $\mathrm{EtOH}$. Each foregut was examined under a dissecting microscope, and the fullness of each stomach estimated visually as a percentage of the total volume occupied by the contents. The dissected contents of each stomach were identified to the lowest taxonomic level (19 species and other categories, Appendix 1), depending on the extent of maceration and digestion, and the presence or absence, as well as the percentage by volume, of each category was estimated visually. Dry 
weight of the total contents was determined to the nearest $0.01 \mathrm{mg}$.

We used log-linear models (SAS Institute Inc. 1988) to test whether the frequency of occurrence of the 19 food categories in predators' stomachs was independent of predator species, month of the season, and sediment type, as well as interactions among factors. The 19 food categories also were used for comparison of diet breadth and overlap among species. Because a full stomach provided more information about the diet of the predators than did an empty one, an average diet composition for each species at each sampling period and station was calculated using the fullness of the stomachs as a weighting factor. The mean proportion of a food category in the diet is

$$
p_{i}=\frac{\sum_{j=1}^{n} x_{i j} y_{j}}{\sum_{i=1}^{19} \sum_{j=1}^{n} x_{i j} y_{j}}
$$

where $\mathbf{x}_{\mathrm{ij}}$ is the proportion of the contents of the ith food category of the $\mathrm{jth}$ individual, and $\mathrm{y}_{\mathrm{j}}$ is the fullness of the stomach of the $j$ th individual. Diet breadth and overlap for each species were calculated as discussed in Colwell \& Futuyma (1971). Breadth of the kth species was

$$
\mathrm{B}_{\mathrm{k}}=1 / \sum_{\mathrm{k}=1}^{4} \mathrm{p}_{\mathrm{kj}}^{2}
$$

where $\mathrm{p}_{\mathrm{kj}}$ is the proportion of species $\mathrm{k}$ which is associated with diet category $\mathrm{j}$. The proportional overlap between 2 species $k$ and $(k+1)$ was

$$
C_{k(k+1)}=1-1 / 2 \sum_{j=1}^{19}\left|p_{k j}-p_{(k+1) j}\right|
$$

for the $\mathrm{j}$ diet categories. The overall overlap of species $\mathrm{k}$ with the other 3 species was estimated by combining the frequencies of other species associated with diet category $j$ and recalculating the overlap as above.

Long-term population fluctuations of clams. To track long-term covariation of prey with predator populations, abundance of the clam Macoma balthica was measured at the river mouth mud trawling station of the Rhode River 4 to 8 times per year from October 1979 to November 1988. Although all other infaunal species were processed for other studies (e.g. Hines et al. 1987a), our focus was restricted to clams as a prey group consumed by only a single predator species Callinectes sapidus and composed predominantly (>98\%) of a single prey species $M$. balthica at this station. This focus provided the treatest chance of observing prey responses to predator fluctuations. Ten cores, $0.008 \mathrm{~m}^{2} \times 35 \mathrm{~cm}$ ceep, were taken by SCUBA divers at haphazard locations within the station during each sampling period. Cores were sieved through $0.5 \mathrm{~mm}$ mesh, fixed in $10 \%$ formaldehyde with rose bengal, and all $M$. balthica counted.

Predator exclusion experiment. Spatial variation in the impact of epibenthic predators was measured with a replicated, full-factorial predator exclusion experiment in 1981. Four cage treatments were deployed at each of 5 locations (Fig. 1) in the subestuary in early June, after the major spring recruitment season, but just before epibenthic predators became active (Hines et al. $1987 \mathrm{a}, \mathrm{b})$. The 5 stations spanned the axis of the river, with 3 stations located on muddy sediments and 2 located on sandy sediments (Fig. 1). At each station, the cage treatments were applied to replicated $0.25 \mathrm{~m}^{2}$ plots haphazardly placed within each location. The treatments consisted of: (1) full cages with a top and 4 sides, $\mathrm{n}=7$; (2) partial cages with a top but only 2 sides, $\mathrm{n}=3$; (3) partial cages with 4 sides but no top, $\mathrm{n}=3$; and (4) uncaged sediment plots, $n=10$. The cages were made of $12-\mathrm{mm}$ meh galvanized hardware cloth bent into cubic shape $50 \mathrm{~cm}$ on a side but with no bottom and pressed $15 \mathrm{~cm}$ into the sediment to prevent predators from burrowing under the sides. All cages were checked weekly for fouling, but the cages remained clean throughout the experiment. After $6 \mathrm{wk}$, in mid-July, each experimental plot was examined for changes in sediment level and sediment size composition, and sampled. A core $0.008 \mathrm{~m}^{2} \times 35 \mathrm{~cm}$ deep was taken from the center of each of the 115 plots. Each core was sieved through $0.5-\mathrm{mm}$ mesh and fixed in $10 \%$ formaldehyde with rose bengal. The organisms retained by the sieve were examined under a dissecting microscope, identified to species, and enumerated. Differences in species abundance among treatments, stations, and treatments $\times$ stations in the predator exclusion experiment were tested by 2-way ANOVA after $F_{\max }$ tests of $\log _{10}$ transformed data indicated homogeneity of variances. When 2-way ANOVA indicated significant interaction between main effects (cage treatment $\times$ station), mean abundances of each dependent variable (log abundance of each infaunal species) were tested for differences among cage treatments at each of the 5 stations using Tukey's simultaneous test for unplanned multiple comparison of means with unequal sample sizes (see Day \& Quinn 1989) as modified by Cicchetti (1972) to avoid confounded comparisons. To test whether reduction in predation pressure by epibenthic fish and crabs enhanced infaunal predatory versus non-predatory species (see Ambrose 1984, 1986, Wilson 1986), differences in the ratio of infaunal predators (Nereis succinea + Eteone heteropoda $\times$ Carinoma tremaphorus) to infaunal prey (sum of other species) among treatments, stations, and their interaction were tested by ANOVA after $F_{\max }$ tests of arcsine-squareroot transformed data 
indicated homogeneity of data. Means were back transformed for graphical presentation.

Bioturbation experiment. To test whether the foraging and movement of the epibenthic guild disturbed the sediments significantly in comparison to disturbance caused by infauna, we conducted a bioturbation experiment in late summer (August 24 to September 7, 1984), when densities of epibenthic predators were high but infaunal densities were low. The experiment was similar in design to the above predator exclusion experiment in that the same 4 cage treatments were used. Each $0.25 \mathrm{~m}^{2}$ experimental plot in the 4 treatments was covered with a 2 to $3 \mathrm{~cm}$ thick layer of dyed sand at the start of the experiment, so that the predatory guild was allowed access to some of dyed sand plots (uncaged and 2 types of partial cage treatments) but was prevented from disturbing dyed sand under full cages. Dyed sand was made by coating $80 \mu \mathrm{m}$ masonry sand with polyurethane resin stained with rhodamine y dye. Thirteen plots of each of the 4 treatments were placed in a randomized grid in $1.5 \mathrm{~m}$ deep water on fine muddy sand (Fig. 1). The dyed sand was carefully laid out by divers in temporary frames to produce a uniform layer on top of undisturbed natural sediment, and cages were placed on appropriate plots. Immediately after setting out the experiment, 3 plots from each of the 4 treatments were sampled as controls ('Time 0') for potential disturbance of the sediment by the divers during deployment of the dyed sand and cages. The remaining 40 experimental plots were sampled after $2 \mathrm{wk}$ by a $0.008 \mathrm{~m}^{2} \times 35 \mathrm{~cm}$ deep core from the middle of each sand plot. Intact cores were transported upright back to the laboratory, and frozen until processing. During processing, we bisected each core longitudinally and photographed the longitudinal sections in color under an ultraviolet light, which was reflected pink by the dyed sand particles. The photographic transparencies were projected onto a fine mesh grid and the number of squares containing dyed sand particles were scored at intervals of about $1 \mathrm{~cm}$ depth below the sediment surface. The distribution of dyed sand into the natural sediment was taken as a measure of bioturbation, either by deposition of sediment on top of the dyed sand or by transport of the sand into the sediment, or both. Differences in vertical distribution of dyed sand among treatments were tested by Kolmogorov-Smirnov tests of the mean cumulative distribution of dyed sand along the vertical levels.

After photographing, the cores were sieved through $0.5-\mathrm{mm}$ mesh and the retained organisms were preserved in $10 \%$ formaldehyde with rose bengal, identified to species under a dissecting microscope and enumerated. Differences in species abundances among the 'Time 0 ' cores and those of the 4 experimental treatments were tested by ANOVA after $\mathrm{F}_{\max }$ tests of log transformed data indicated homogeneity of variances, although means were back transformed for presentation.

In addition, the abundances of epibenthic fish and crabs at the experimental site were estimated during the 2 wk experimental period with a drop net similar in design to that described by Gilmore et al. (1978). The net was made from a $7-\mathrm{mm}$ mesh minnow seine on a square frame $3 \mathrm{~m}$ on a side suspended above the water surface from a tripod. When the net was triggered remotely, the weighted bottom edge dropped to conform to the contours of the sediment while the top of the net remained above the water surface. All animals were removed from the enclosure by seining repeatedly until nothing could be caught and visual inspection by divers indicated that no fish or crabs remained. The drop net was deployed 20 times around the periphery of the experimental plots during the $2 \mathrm{wk}$ period of the bioturbation experiment.

Clam survivorship experiment. To clarify the effect of predator exclusion on a species which did not show a spatially consistent ranking among predator exclusion treatments we conducted an additional experiment on Macoma balthica, which comprised a large fraction of the stomach contents of blue crabs. We hypothesized that some of the spatial variability in the predator exclusion experiment resulted from lateral movement of prey out of the cage refuges, confounding the experiment. We measured the survivorship of 25 to $35 \mathrm{~mm} M$. balthica placed in experimental buckets of mud set in $1.5 \mathrm{~m}$ of water near the head of the subestuary (Fig. 1) from August 8 to September 28, 1981. The buckets prevented lateral movement of the clams out of the experimental plots. Four replicate 201 buckets were assigned to each of 2 treatments: uncaged buckets, and buckets caged with $12-\mathrm{mm}$ mesh galvanized hardware cloth in a cylindrical cap extending $20 \mathrm{~cm}$ above the bucket's rim. The mud in the buckets was collected from the subestuary and sieved through $3-\mathrm{mm}$ mesh. Thirty clams were placed on the sediment surface of each bucket and allowed to bury over $24 \mathrm{~h}$ before placing the buckets into the subestuary. Preliminary tests showed that the $24 \mathrm{~h}$ period was long enough for the clams to bury to a constant average depth of 15 to $25 \mathrm{~cm}$. The number of live and dead clams after the experimental period was tested for independence of caging treatment by the Chi-squared distribution in a G-test.

\section{RESULTS}

\section{Species composition of the guild}

Over the 8 yr of trawling, 38 species were caught, but only 6 species Leiostomus xanthurus, Anchoa mitchilli, 
Table 1. Species composition of otter trawl catch in Rhode River subestuary from 1981 to 1988

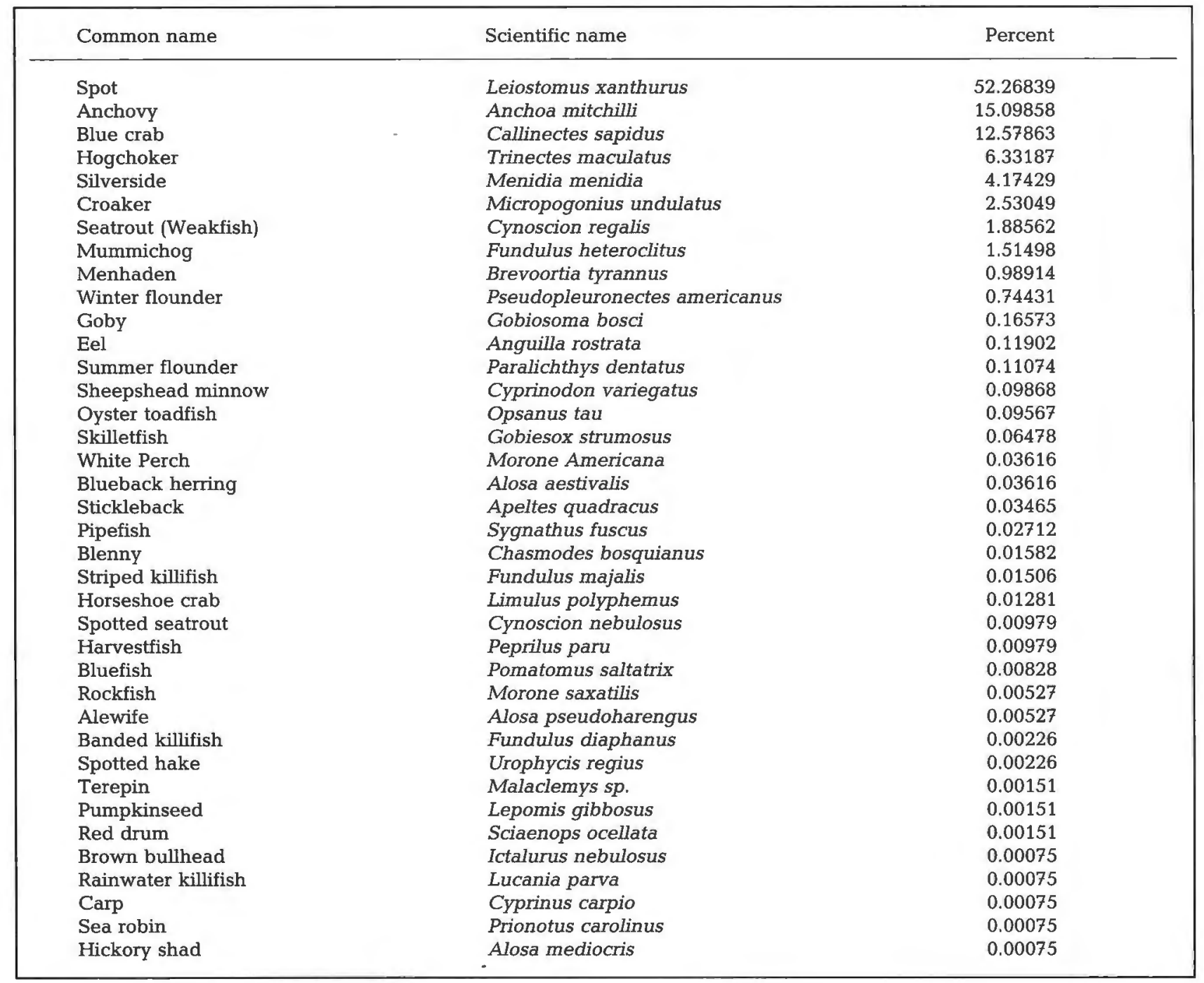

Callinectes sapidus, Trinectes maculatus, Micropogonias undulatus, and Menidia menidia accounted cummulatively for $95 \%$ of the catch, while 28 species individually made up less than $0.5 \%$ of the catch (Table 1). Species composition of the 38 species as measured by their rank order did not differ significantly among years (Friedman's method for randomized blocks, $\chi^{2}=207.3, \mathrm{df}=37, \mathrm{p}<0.001$ ). Rank order of the 6 most abundant species and of the remaining 33 less abundant species also did not change significantly among years when the 2 groups were considered separately (Friedman's method for randomized blocks, respectively: $\chi^{2}=15.7$, df $=5, \mathrm{p}<0.01 ; \chi^{2}=$ 135.8 , df $=31, \mathrm{p}<0.001$ ). However, a major shift in species composition of the numerically dominant members of the guild occurred in 1983, when the abundance of $L$. xanthurus dropped drastically and the abundance of another sciaenid, M. undulatus, increased greatly
(Fig. 2). In 1987 L. xanthurus again comprised a low percentage of the catch, but $M$. undulatus did not increase (Fig. 2). All common species exhibited similar large annual fluctuations in their relative abundance (Fig. 2). Of the 6 common species, only 4 L. xanthurus, $T$. maculatus, $C$. sapidus, and $M$. undulatus are known to be benthic feeders, while $A$. mitchilli and $M$. menidia are filter feeders and planktivores, respectively, in the water column and thus are not truly members of the epibenthic predatory guild (Carr \& Adams 1973, Horwitz 1987, Baird \& Ulanowicz 1989).

\section{Population dynamics and size structure of main guild species}

Analysis of the population dynamics of the 4 common predatory species showed that their abundances fluctu- 


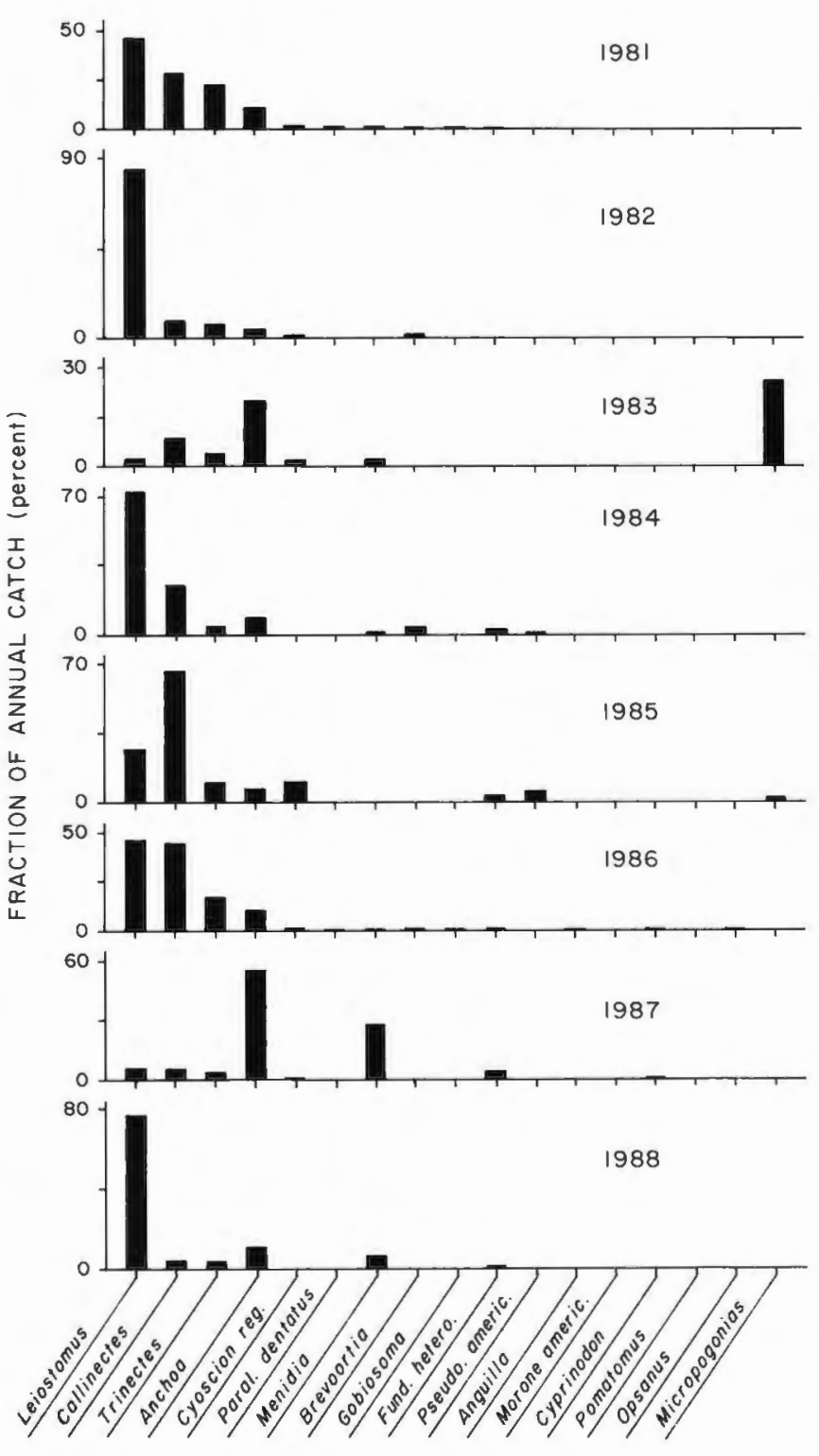

Fig. 2. Annual variation in species composition of otter trawl catch from 1981 to 1988 in Rhode River subestuary. Species order is arranged by rank of the 17 most abundant species in 1981. Complete species names are listed in Table 1

ated seasonally with peaks in summer and nearly no organisms caught in December and April (Fig. 3). When seasonal variation was partitioned by trigonometric functions using ANCOVA, each of the 4 species varied significantly in abundance among years, while all but Micropogonias undulatus varied significantly among stations, and in year $\times$ station interactions (Table 2). All of the species underwent several fold fluctuation in abundance among years; and the catch of most species was usually lowest at the station at the head of the subestuary, except in 1988, when abundances at this station were higher than at the mouth of the subestuary. Leiostomus xanthurus abundance declined markedly at all stations in 1983 and again to a lesser extent in 1987. M. undulatus increased markedly at all stations in 1983 and at 2 stations in fall of 1985, but it was absent in other years. The area sampled by each trawl was ca $1800 \mathrm{~m}^{2}$, and, assuming the gear had catch efficiencies of about $23 \%$ for Callinectes sapidus, $21 \%$ for $L$. xanthurus and $M$. undulatus, and $24 \%$ for Trinectes maculatus as derived for these species with similar gear in similar habitat (Kjelson \& Johnson 1978, Homer et al. 1980), the peak densities per $\mathrm{m}^{2}$ of the 4 species fluctuated among years in the following ranges: $C$. sapidus $=0.08$ to $0.63 ; L$. xanthurus $=0.01$ to $3.8 ; M$. undulatus $=0.0$ to 0.63 ; and $T$. maculatus $=0.05$ to 0.18 .

Size frequency distributions of the 4 common epibenthic species showed seasonal cycles in population structure which were distinct among species but consistent among years within each species (Figs. 4 and 5). Both Leiostomus xanthurus and Micropogonias undulatus populations were comprised of a single size-class; however, $L$. xanthurus moved into the Rhode River subestuary at about $35 \mathrm{~mm}$ in length in May, while $M$. undulatus entered the system at about $35 \mathrm{~mm}$ in length in November (Fig. 4). Both of these fish species showed rapid growth throughout the summer until $L$. xanthurus reached a modal length of $115 \mathrm{~mm}$ in November, and $M$. undulatus grew to about $175 \mathrm{~mm}$ in October. From December through April of each year, $L$. xanthurus was not present in the Rhode River, whereas small $M$. undulatus apparently overwintered in the subestuary in 1982/83 and again in lesser abundance in 1985/86 before the 2 summers of relatively high abundance. In contrast to the 2 sciaenid species, the Trinectes maculatus population was composed of 3 size-classes, which had distinct modes at 45,85 and $115 \mathrm{~mm}$ length in April, and which grew through the summer (Fig. 4). $T$. maculatus were first caught at a size of about $45 \mathrm{~mm}$ in late September and October, and low abundances of these recruits apparently remained in the subestuary over winter while the larger size-classes left.

The Callinectes sapidus population exhibited 2 sizeclasses with modes at about 25 and $95 \mathrm{~mm}$ carapace width in both males and females in April (Fig. 5). These 2 size-classes reflect recruitment of new juveniles and reactivation of overwintering crabs. The 2 size-classes showed rapid growth and maturation of the larger class throughout the summer until males had modes at about 75 and $120 \mathrm{~mm}$ and females had modes at about 115 and $155 \mathrm{~mm}$. Small (ca $25 \mathrm{~mm}$ ) crabs began recruiting into the subestuary in October and November. As indicated by comparing the size structure of the blue crab population in July for 1984 and 1985 (Fig. 6), the major increases in abundance of blue crabs in 1984 and 1985 (Fig. 3) appear to have resulted from a single major 

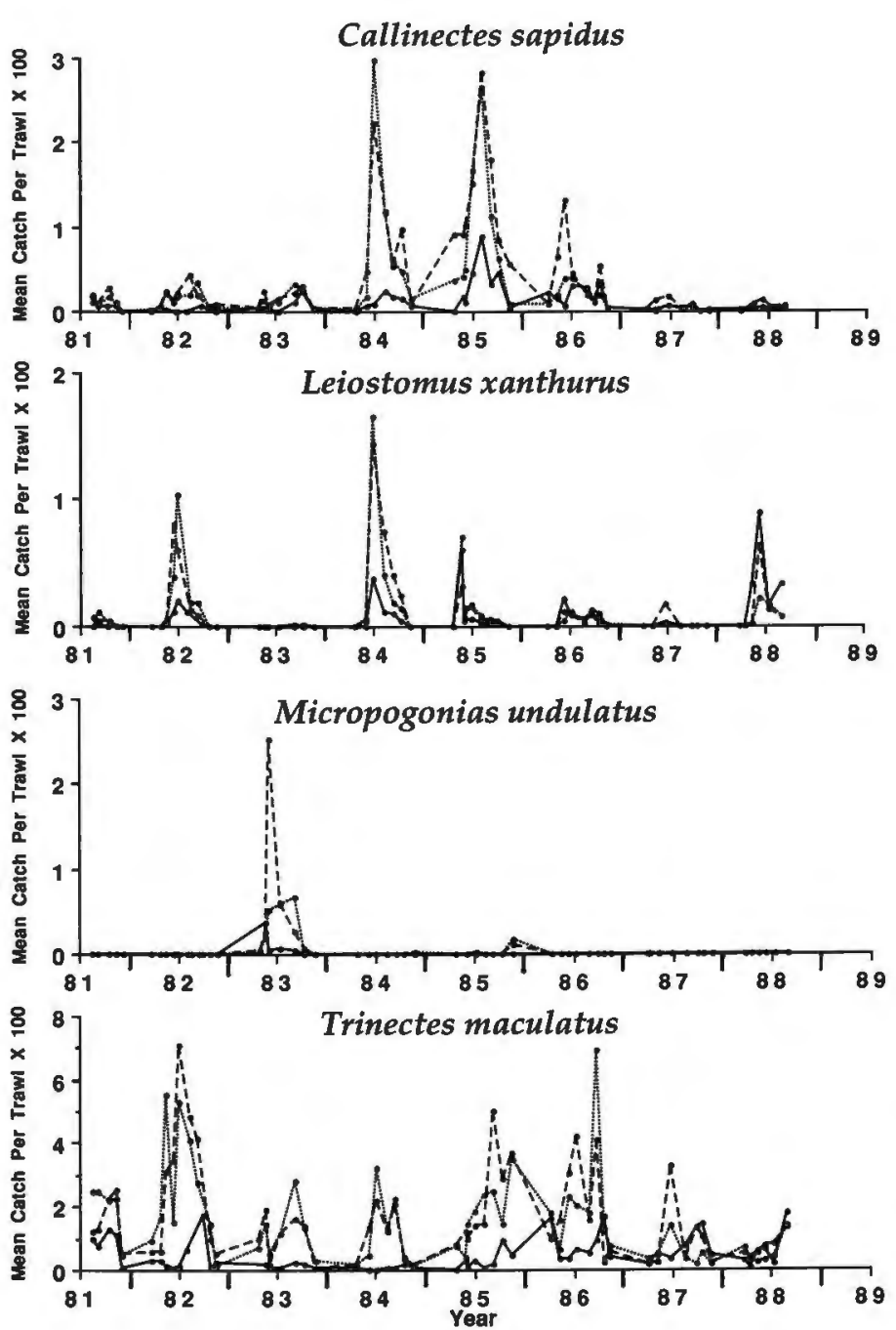

recruitment of crabs in 1984, which carried over into the second year-class in 1985. In July 1984 the smaller size-class comprised $73 \%$ of the population and the large size-class was $27 \%$ of the population; after growing until July 1985 the first size-class comprised $67 \%$ and a new small size-class was $33 \%$ of the population (Fig. 6).
Fig. 3. Population abundances of the 4 common species in the guild of epibenthic predators in the Rhode River subestuary. Monthly mean numbers of individuals per otter trawl are plotted for each of the 3 stations shown in

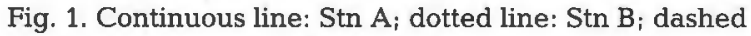
line: Stn C

Table 2. Analysis of covariance of otter trawl catch for the 4 dominant members of the guild of epibenthic predators in the Rhode River subestuary from 1981 to 1988 (see Fig. 3). Trigonometric functions were used as covariates to partition variation due to seasonal cycles while testing for effects of year and station, as well as their interaction. F-values are shown; $\mathrm{p}=\cdots * 0.001, \cdots<0.01, *<0.05, \mathrm{NS}=$ not significant

\begin{tabular}{lccc|}
\hline Species & Year & Station & Year $\times$ Station \\
\hline Callinectes sapidus & $51.98^{* *}$ & $45.39^{* * *}$ & $3.91^{* *}$ \\
Leiostomus xanthurus & $32.08^{* *}$ & $4.64^{* *}$ & $1.86^{*}$ \\
Micropogonias undulatus & $3.83^{* *}$ & $0.63^{\mathrm{NS}}$ & $0.79^{\mathrm{NS}}$ \\
Trinectes maculatus & $13.87^{* * *}$ & $78.61^{* * *}$ & $5.96^{* * *}$ \\
\hline
\end{tabular}


Fig. 4. Seasonal cycles of population structure for the 3 common species of fish in the guild of epibenthic predators. Average monthly sizefrequency distributions of fish in otter trawl catches in the Rhode River from 1981 to 1988 are plotted. Measured sample sizes are indicated for each histogram
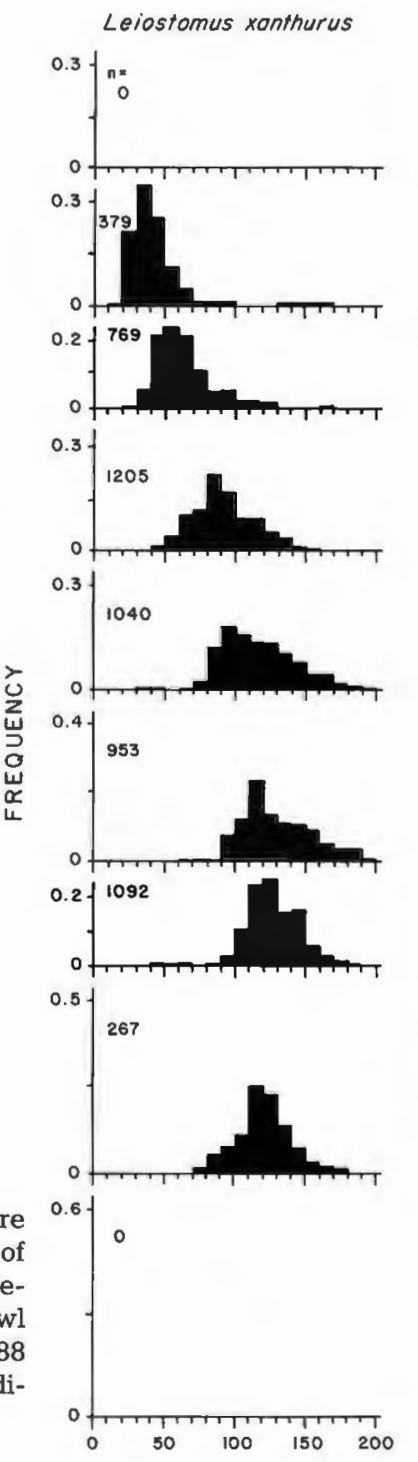
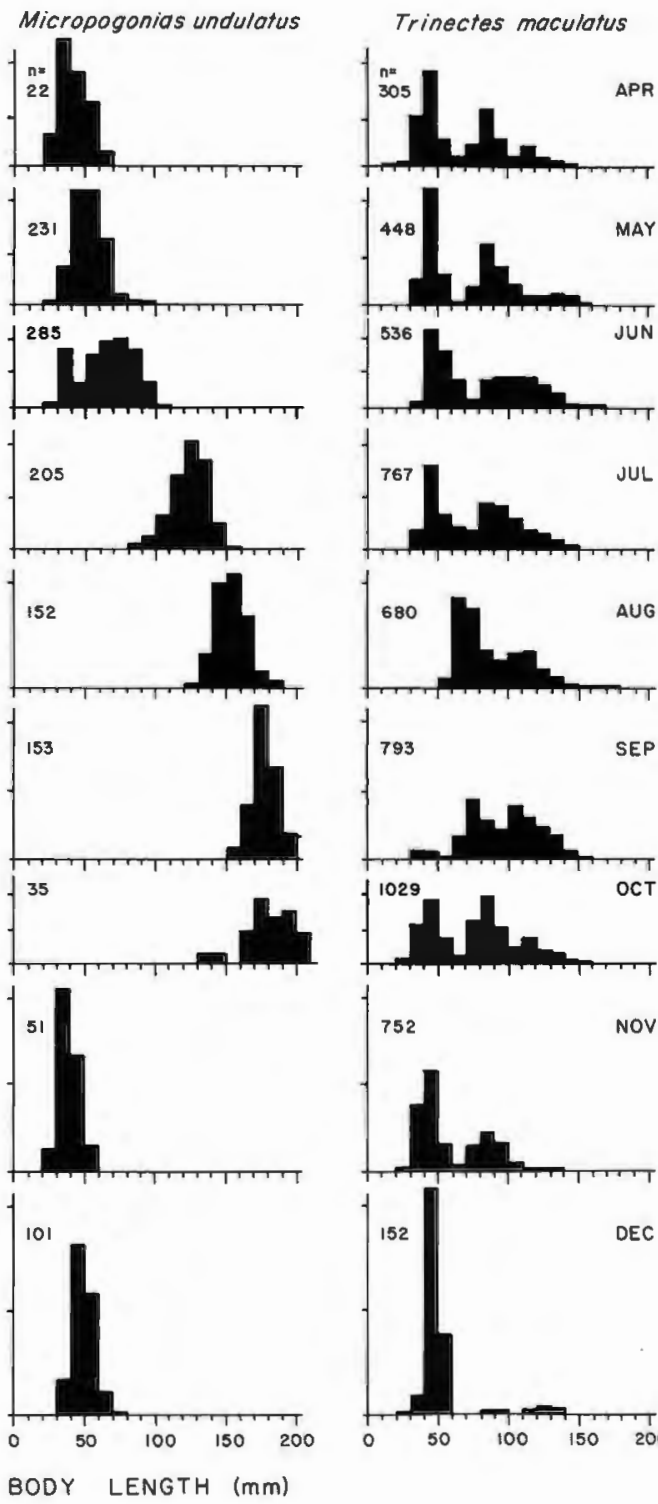

digested to identify to taxon. Remarkably little sediment and detritus, and almost no plant material, were found in their stomachs. Stomachs of Callinectes sapidus contained mainly ( 30 to $55 \%$ ) clams with lesser amounts of fish and blue crabs, as well as about $25 \%$ amphipods in June (Fig. 7, Appendix 1). Leiostomus xanthurus consumed primarily Macoma balthica siphons and small crustaceans, along with meiofauna in June and a variety of polychaetes throughout the year (Fig. 7, Appendix 1). Micropogonias undulatus fed extensively on amphipods in June, but we have no data for this species in September (Fig. 7, Appendix 1). Trinectes maculatus also fed extensively on amphipods as well as on ca 20 to $25 \%$ M. balthica siphons and a variety of polychaetes (Fig. 7 , Appendix 1). The frequency of occurrence of particular food items in predator stomachs varied significantly among species for all but two of the 19 food categories (Table 3 ; log-linear analysis, $p<0.05$ ). The presence of only 7 food categories in predators' stomachs varied significantly between months (June, September) (Table 3 ; $\log$-linear analysis, $\mathrm{p}<0.05$ ). The incidences of other blue crabs and clams in Callinectes sapidus stomachs increased significantly later in the season, while amphipods declined (Fig. 7, Appendix 1; loglinear analysis, $\mathrm{p}<0.01$ ). The incidence of $M$. balthica siphons increased significantly in $L$. xanthurus and T. maculatus later in the season, while the incidence of meiofauna in $L$. xanthurus declined (Fig. 3, Appendix 1). The presence of all of the food categories was independent of sediment type (Table 3). Although the presence of 7 food categories in predators' stomachs depended on the interaction between predator species and month of the season, 


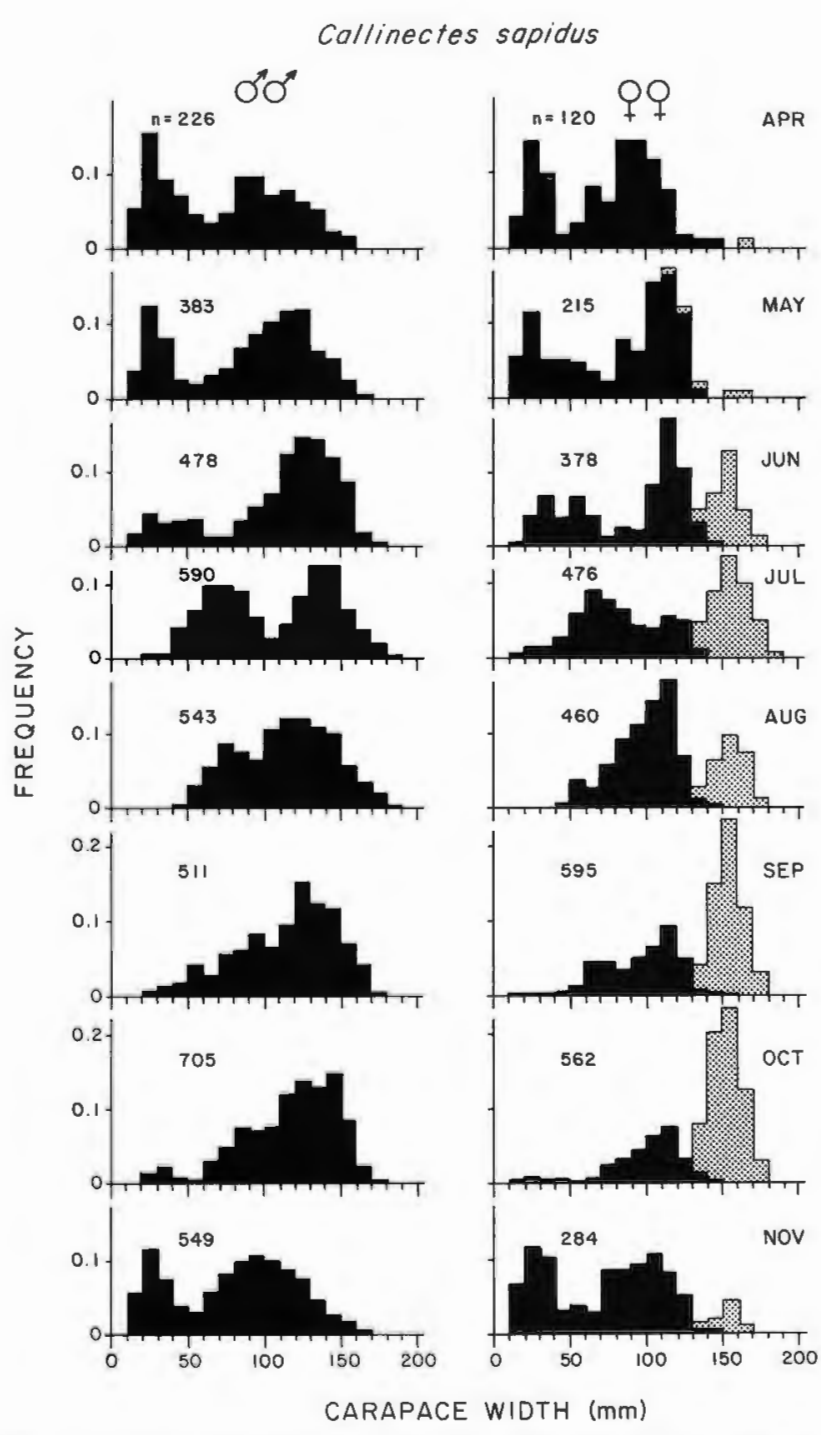

Fig. 5. Seasonal cycles of population structure for male and female blue crabs. Average monthly size-frequency distributions of crabs in otter trawl catches in the Rhode River from 1981 to 1988 are plotted. Stippled histograms indicate mature females. Measured sample sizes are indicated for each histogram

there were no other significant interactions (Table 3).

Indices of dietary breadth and overlap within the guild reflected aspects of both shifting specialization and considerable overlap among the predators (Table 4). Although the guild as a whole consumed the diverse array of food categories (Appendix 1), none of the samples for a species approached the theoretical maximum value of 19. Ranging toward the specialized end of the spectrum with values from 1.9 to 6.1 , dietary breadth varied with predator species, season, and to a lesser extent with sediment type. However, no pattern of variation in diet breadth was apparent. For example, Trinectes maculatus had both the narrowest and the
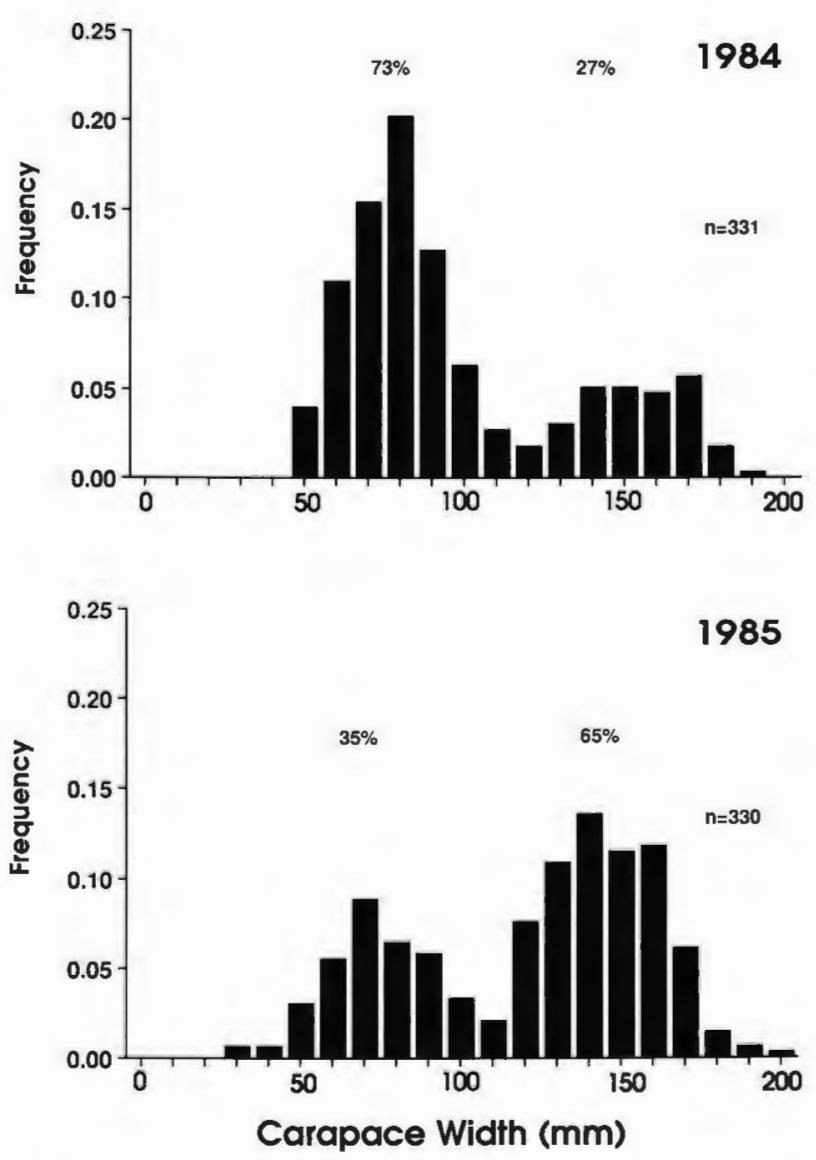

Fig. 6. Size-frequency distributions of blue crabs in summers (July) of 1984 and 1985 showing the shift in age distribution from more than two thirds of the population in the first yearclass to nearly two thirds in the second year-class following a major recruitment of crabs in 1984

broadest indices. Whereas dietary breadth in Callinectes sapidus was wider in June than September, dietary breadth in T. maculatus and Leiostomus xanthurus tended to be wider late in the season. Diet breadth indices were similar for the 2 sediment types in $C$. sapidus and Micropogonias undulatus but tended to be different in T. maculatus and $L$. xanthurus, although the broader index was not consistently associated with either of the sediment types. Dietary overlap of each of the species with other guild members was fairly high (54 to $73 \%$ ) and uniform across months of the season and sediment types (Table 4). Pairwise overlaps between the fish species were similarly high (43 to $77 \%$ ) and fairly uniform; however, pairwise dietary overlaps between $C$. sapidus and the fish were considerably lower ( 4 to $30 \%$ ), particularly late in the season when crabs fed extensively on clams and on other blue crabs while fish took siphons and an array of infauna. Although these indices of breadth and overlap do not provide for statistical tests of significance (Colwell \& Futuyuma 1971), we are confident in the reality of their 


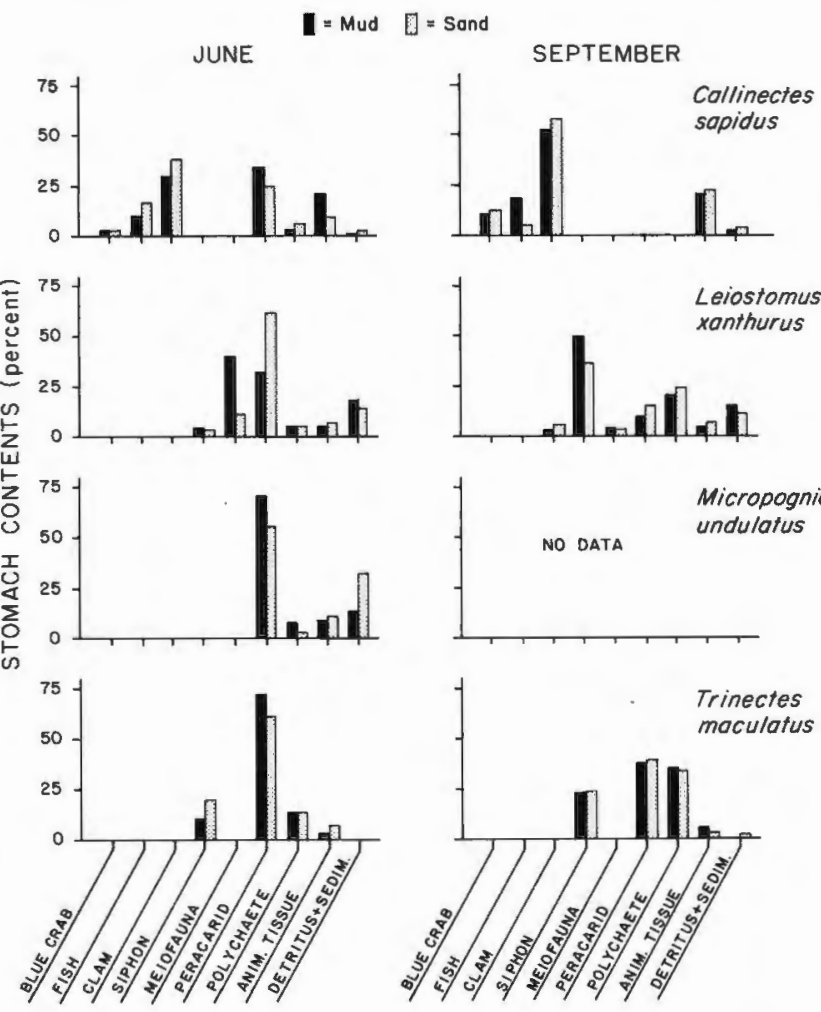

Fig. 7. Composition of stomach contents of the 4 common species of epibenthic predators in the Rhode River subestuary. Fraction of stomach contents indicated for each of 9 food categories in June and September for samples collected by otter trawl over muddy and sandy sediments at Stns B and C in Fig. 1

general patterns. The patterns are consistent with both the stomach content data and the ranges of variability observed in other guilds (e.g. Hines 1982, Livingston 1984).

\section{Population fluctuations of blue crabs and Macoma balthica}

Abundances of Macoma balthica at the river mouth exhibited a pattern of fluctuations apparently responding to variation in predatory blue crabs as well as recruitment of larval clams (Fig. 8). Prey densities were low at about 200 clams m$^{-2}$ in $1979 / 80$, and no data are available for predator abundance during this period. In the spring of 1981, prey densities increased markedly, reaching a peak of ca 2700 clams $\mathrm{m}^{-2}$ in early summer 1981. Clam densities following this major recruitment peak declined precipitously as predators became active throughout the summer. However, clam densities remained relatively constant at a new, elevated level of ca 600 to 700 clams m $^{-2}$ throughout 1982, 1983 and early 1984 , with more typical spring recruitment peaks
Table 3. Log-linear analysis of independence of stomach contents for predator species (Callinectes sapidus, Leoistomus xanthurus, Micropagonias undulatus, Trinectes maculatus), month of season (June, September), and sediment type (mud, sand). UP: unidentified polychaetes; DAT: digested animal tissue. Main and all interactive effects of sediment type were not significant, and are not listed. Chi-square values are shown only for main effects and interactions of predator and month. $\mathrm{p}={ }^{*}<0.05,{ }^{* *}<0.01,{ }^{*}{ }^{*}<0.001, \mathrm{NS}=$ not significant

\begin{tabular}{|llll|}
\hline Contents category & Predator & Month & $\begin{array}{c}\text { Predator } \\
\times \text { Month }\end{array}$ \\
\hline Callinectes sapidus & $*$ & $*$ & NS \\
Fish & $* *$ & NS & NS \\
Clams & $* * *$ & $* *$ & $* *$ \\
Macoma balthica siphons & $* * *$ & $* * *$ & $* *$ \\
Copepods & $* * *$ & NS & $* *$ \\
Nematodes & $* * *$ & NS & $* *$ \\
Mysids & $*$ & $*$ & $*$ \\
Cyathura polita & $* *$ & NS & NS \\
Corophium lacustre & NS & NS & $* * *$ \\
Leptocheirus plumulosus & $* * *$ & $* * *$ & NS \\
Chironomids & $* * *$ & $* *$ & NS \\
Heteromastus filiformis & $* * *$ & NS & NS \\
Eteone heteropoda & $* *$ & NS & NS \\
Nereis succinea & NS & NS & $* * *$ \\
Scolecolepides viridis & $*$ & NS & NS \\
UP & $* * *$ & $* *$ & NS \\
DAT & $* * *$ & NS & NS \\
Detritus & $* * *$ & NS & NS \\
Sediment & $* * *$ & NS & NS \\
& & & \\
\hline
\end{tabular}

of ca 800 to 1000 clams $\mathrm{m}^{-2}$. During this period, crab densities were relatively low each summer, with peaks coinciding with the summer decline in clams. During late 1984 to 1987 , clams showed little recruitment and densities declined progressively to low levels approximating those in 1979/80. The return of clam densities to this low level coincided with the marked increase in crab abundances in the summers of 1984 and 1985.

\section{Predator exclusion experiment}

Neither fouling, changes in sediment level, nor changes in the size fractions of sediments (ANOVA, $p>0.2$ ) occurred in any of the treatments at any of the 5 stations during the experimental period, so we judged cage artifacts to be minimal, especially in view of the experimental design of deploying cages after the spring period of infaunal recruitment. Observations of the cages by divers during the experiment indicated that no crabs or fish larger than $12 \mathrm{~mm}$ entered any of the full cages. Blue crabs readily entered the 2 types of partial cages (no top and two-sided), but no sciaenids and only rare flat fish were observed within the partial cages. Densities of infaunal invertebrates did not differ significantly between the no-top and 2-sided cages for 
Table 4. Dietary breadth and overlap based on stomach contents by month and sediment type. Values of dietary breadth for the 19 food categories in Appendix 1 have a theoretical range from 1 for a perfect specialist on one food item to 19 for a perfect generalist feeding on all items equally. Dietary overlap values indicate fraction of diet in common ranging from 0 to 1.0 . ND: no data

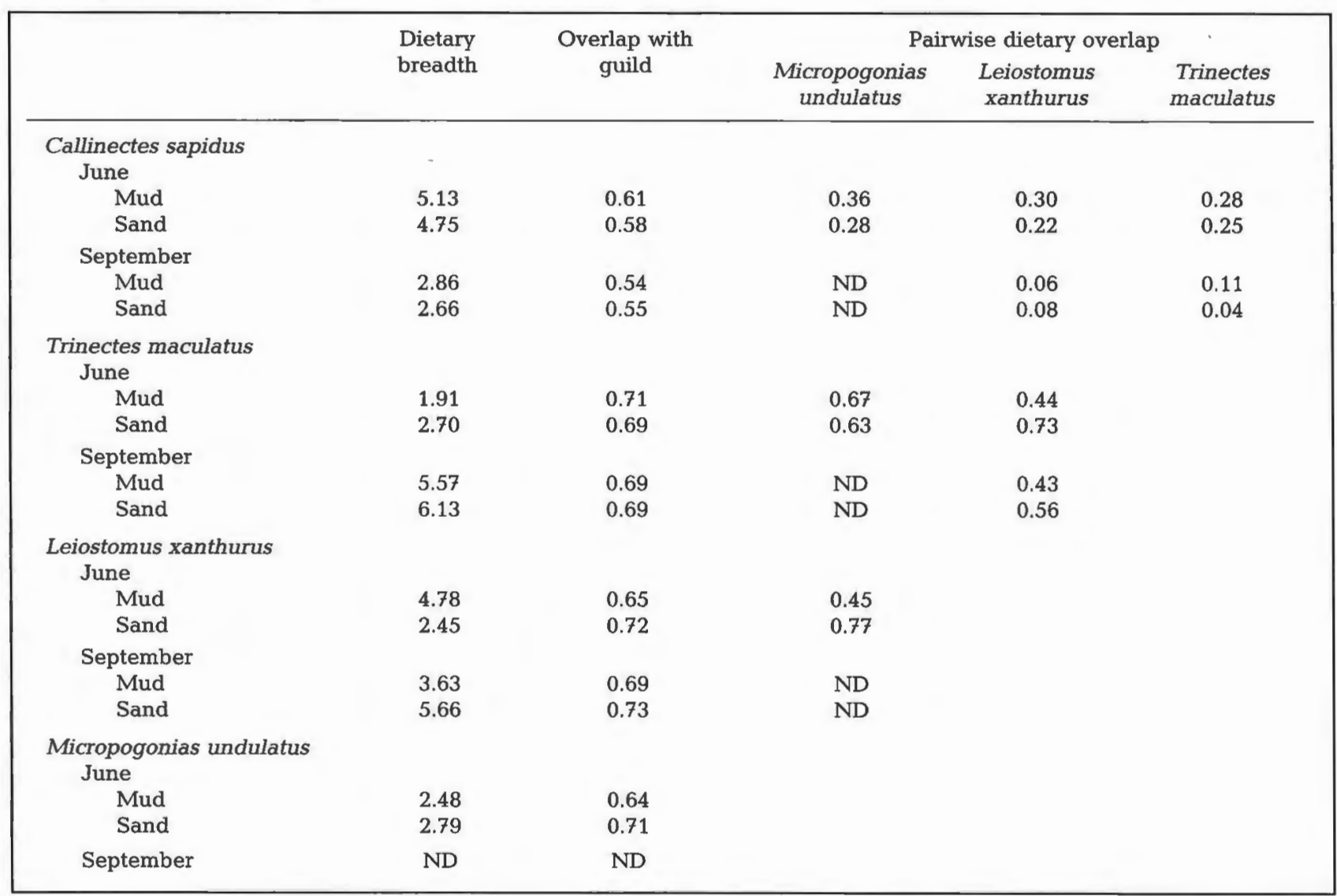

any species across all stations and at each station individually (1-way ANOVA, $\mathrm{p}>0.09$ ), so data for the 2 types of partial cages were pooled in subsequent analyses of cage treatments. Both the effect of the partial

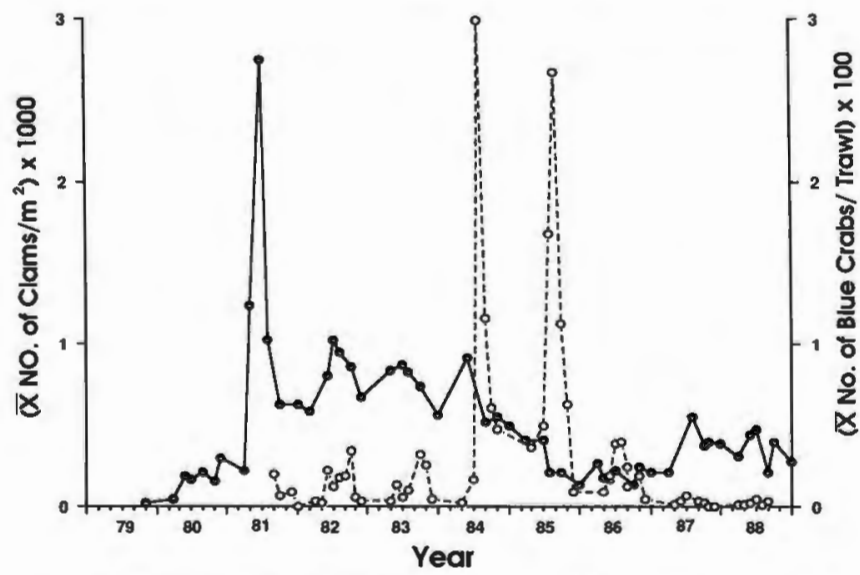

Fig. 8. Covariation of predatory blue crab (dashed line) and Macoma balthica prey (continuous line) populations in the Rhode River. Mean densities of clams in benthic cores at Stn IV, and of blue crabs in otter trawls at Stn B are plotted cages in excluding predatory species differentially and the lack of any apparent cage artifacts indicate that the partial cages did not function as true cage controls. We think that these cages should be viewed simply as another type of treatment that reduced the access to infaunal prey by some predators but not by others, perhaps resulting in a level of predation which was intermediate between those in full-cage and no-cage treatments.

Abundances of infaunal species in the uncaged control plots declined markedly during the course of the experiment as predators fed from June to mid-July (e.g. see 1981 period in Fig. 8 and Hines et al. 1987a). The total abundances of infaunal organisms surviving in caged plots were significantly higher than in uncaged plots, and there was significant spatial variation (effect of station) in the experiment (Fig. 9A, Table 5; 2-way ANOVA, $p<0.001$ ). There was also significant interaction between cage treatment and station (Table 5); however, cage effects were significant at 4 of the 5 stations [Fig. 9A, 2-way ANOVA, $p<0.01$; Cicchetti's (1972) modification of Tukey's simultaneous unplan- 
Fig. 9. Predator exclusion experiment. Least-squares mean densities of (A) total infaunal organisms and of (B) the ratio of predatory infauna (Nereis succinea + Eteone heteropoda + Carinoma tremaphorus) to prey infauna (all other species) are shown for experimental plots treated with full, partial, and no exclusion cages. Main effects of cage treatment, station, and their interaction were tested by 2-way ANOVA for all stations, ${ }^{* *}=p<0.001$. At each station, least-squares means which do not differ significantly are connected by brackets (Cicchetti's modification of Tukey's simultaneous tests for unplanned multiple comparison of means, $p=0.05$ )
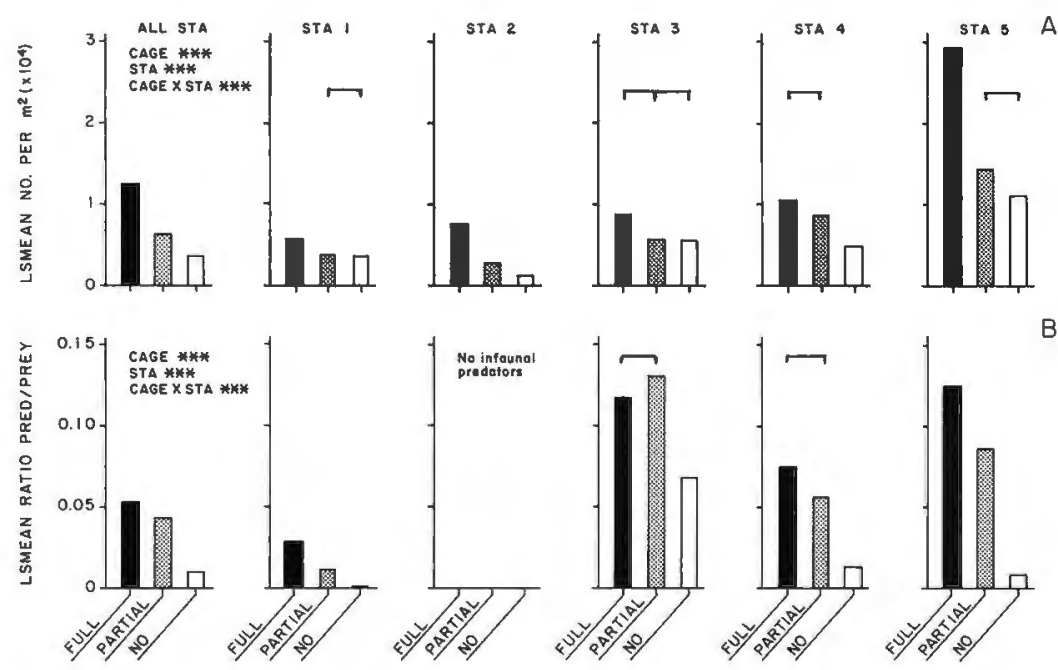

A

ned multiple comparison of means with unequal sample sizes, $p<0.05$ ]. Infaunal densities in the partial cages were intermediate between those of full cages and uncaged plots, and the ranking of abundance in the 3 treatments was the same for each of the stations and for the stations combined (Fig. 9A). This consistency in pattern among stations indicates that the interaction between main effects resulted from variations in abundance of infaunal species and varying degree of impact of predators among locations, rather than qualitative spatial differences in the impact of the guild.

The ratio of the abundance of the predaceous infaunal guild (in the Rhode River subestuary the polychaetes Eteone heteropoda and Nereis succinea, and the nemertean Carinoma tremaphorus) to the
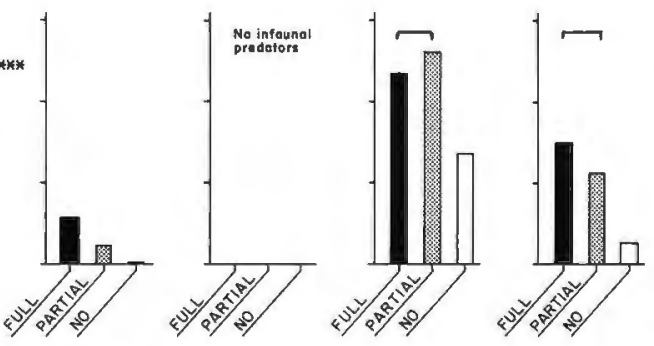

B

abundance of the other, non-predaceous infaunal species was significantly greater in the full cage treatment than in the uncaged plots across all stations. The ratios differed significantly among stations, and there was significant interaction between the main effects [Fig. 9B; 2-way ANOVA of arc-sin square root transformed ratios, $p<0.001$; Cicchetti's (1972) modification of Tukey's simultaneous unplanned multiple comparison of means with unequal sample sizes, $p<0.05]$. The ratio of infaunal predators to prey was significantly higher in the full cage treatment at 4 of the 5 stations. The ratios of infaunal predators to prey in the partial cages were intermediate between the full and no cage treatments for the combination of all stations and at 3 of the individual stations (Fig. 9B).

Twenty-seven species comprised the macro-infauna

Table 5. Analysis of variance for predator exclusion experiment. F-values for main effects (cage, station) and interaction in 2-way ANOVA are shown. $\mathrm{p}={ }^{*}<0.05, \cdots<0.01,{ }^{* * *}<0.001, \mathrm{NS}=$ not significant

\begin{tabular}{lccc}
\hline & Cage & Station & Cage $\times$ Station \\
\hline Macoma balthica & $5.19^{* *}$ & $42.78^{* *}$ & $1.79^{\mathrm{NS}}$ \\
Macoma mitchelli & $35.2^{* * *}$ & $36.2^{* * *}$ & $8.13^{* * *}$ \\
Mya arenaria & $4.76^{* *}$ & $44.36^{* * *}$ & $3.57^{* *}$ \\
Mulinia lateralis & $7.18^{* *}$ & $4.63^{* *}$ & $5.40^{* * *}$ \\
Heteromastus filiformis & $5.76^{* *}$ & $15.28^{* * *}$ & $1.34^{\mathrm{NS}}$ \\
Eteone heteropoda & $5.51^{* *}$ & $152.17^{* * *}$ & $10.25^{* * *}$ \\
Laeoneris culveri & $2.71^{\mathrm{NS}}$ & $48.50^{* *}$ & $5.55^{* * *}$ \\
Nereis succinea & $20.0^{* * *}$ & $87.75^{* * *}$ & $11.14^{* *}$ \\
Scolecolepides viridis & $0.21^{\mathrm{NS}}$ & $20.37^{* * *}$ & $1.21^{\mathrm{NS}}$ \\
Streblospio benedicti & $44.07^{* * *}$ & $31.37^{* * *}$ & $8.24^{* * *}$ \\
Tubificoides spp. & $4.88^{* *}$ & $2.12^{\mathrm{NS}}$ & $6.08^{* * *}$ \\
Edotea triloba & $3.87^{* *}$ & $19.44^{* * *}$ & $3.22^{* *}$ \\
Cyathura polita & $12.42^{* * *}$ & $11.89^{* * *}$ & $1.68^{\mathrm{NS}}$ \\
Corophium lacustre & $1.60^{\mathrm{NS}}$ & $24.38^{* * *}$ & $4.07^{* * *}$ \\
Leptocheirus plumolosus & $10.03^{* * *}$ & $42.83^{* * *}$ & $4.56^{* * *}$ \\
Carinoma tremaphorus & $85.09^{* * *}$ & $45.26^{* * *}$ & $5.60^{* * *}$ \\
Total organisms & $45.61^{* * *}$ & $51.11^{* * *}$ & $5.98^{* * *}$ \\
Ratio of infaunal predators/prey & $29.15^{* * *}$ & & $3.36^{* *}$ \\
\hline
\end{tabular}




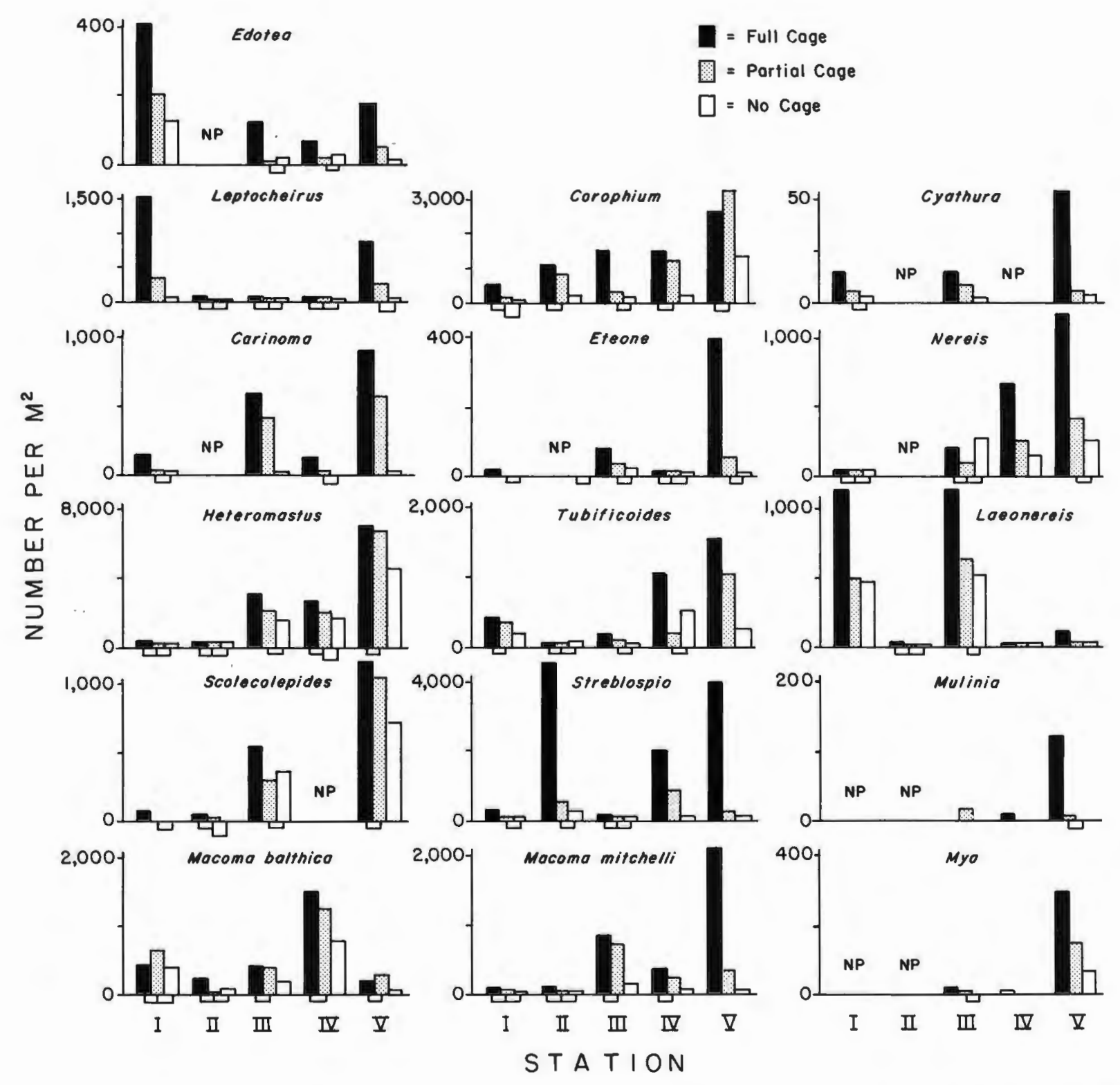

Fig. 10. Predator exclusion experiment. Least-squares mean densities of 16 common infaunal species are shown for experimental plots treated with full, partial, and no exclusion cages at each of 5 stations. Means which do not differ significantly are connected by bottom brackets (Cicchetti's modification of Tukey's simultaneous tests for unplanned multiple comparison of means, $\mathrm{p}=0.05$ )

in the experimental plots. However, only 16 species had mean densities that were significantly greater than 0 for at least one treatment at one station (Students ttests, $\mathrm{p}<0.05$ ); so we compared densities of only these species among treatments (Table 5). Most (13) species differed significantly among cage treatments, and most (15) species also differed significantly among stations. However, most (12) species also exhibited significant treatment $\times$ station interactions (Table 5), so we also tested the effect of cage treatment on the 16 species at each of the 5 stations [Cicchetti's (1972) modification of Tukey's simultaneous unplanned multiple comparison of means with unequal sample sizes, $\mathrm{p}<0.05$; Fig. 10]. Most (11) species showed a significantly consistent rank order among cage treatments across stations, with highest densities in full cages, intermediate densities in partial cages, and lowest densities in uncaged plots: Macoma mitchelli, Heteromastus filiformis, Streblospio benedicti, Corophium lacustre, Leptocheirus plumulosus, Carinoma tremaphorus, Laeonereis culveri, Mya arenaria, Mulinia lateralis, Edotea triloba, and Eteone heteropoda (Friedman's method for randomized. blocks, $\mathrm{p}<0.05$; Fig. 10). In 5 other species, rank of abundance in cage treatments varied among stations: 


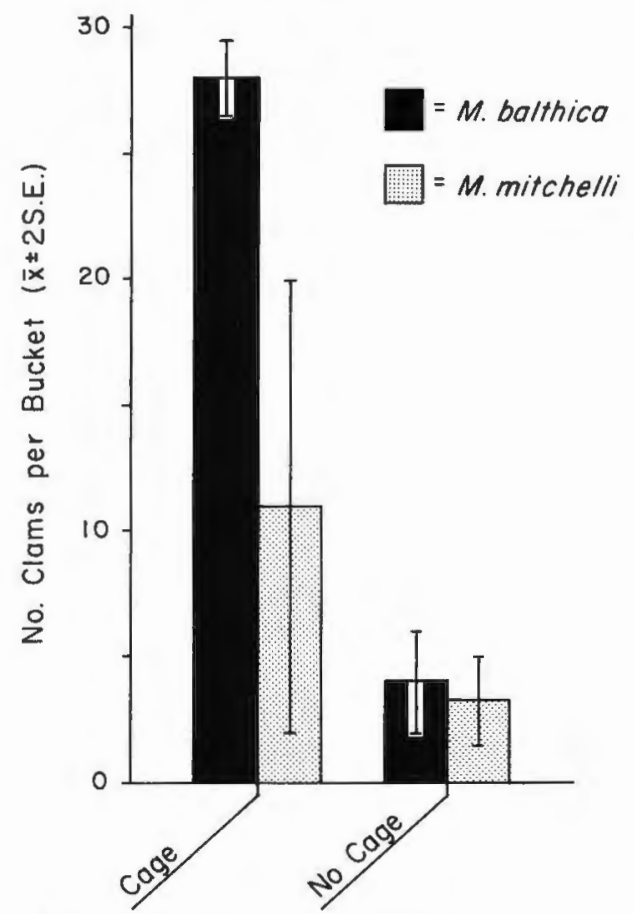

Fig. 11. Number of clams surviving in caged and uncaged buckets placed in Rhode River subestuary for 2 wk. Initially, 30 large Macoma balthica were planted in each bucket. $M$. mitchelli recruited into the buckets during the experiment

Macoma balthica, Nereis succinea, Cyathura polita, Scolecolepides viridis, and Tubificoides spp. (Friedman's method for randomized blocks, $\mathrm{p}>0.05$; Fig. 10).

\section{Clam survivorship experiment}

Survivorship of Macoma balthica in caged buckets $(\overline{\mathrm{X}}=28$ clams $)$ was significantly greater than that of clams in uncaged buckets ( $\overline{\mathrm{X}}=4$ clams) (Fig. 11; log- linear model using maximum likelihood, $\chi^{2}=81.31, \mathrm{df}$ $=1, \mathrm{p}<0.001$ ). In addition, more Macoma mitchelli $>0.5 \mathrm{~mm}$ in length recruited and survived in the caged buckets $(\overline{\mathrm{X}}=11.5)$ than in the uncaged buckets $(\overline{\mathrm{X}}=$ $3.3)_{i}$ however, the difference was not statistically significant (Fig. 11; ANOVA, p >0.05), because recruitment in the $2 \mathrm{wk}$ test period was highly variable among buckets.

\section{Bioturbation experiment}

Densities of infaunal invertebrates were low in the experimental plots and did not differ among treatments, except for Heteromastus filiformis, which had lower densities in the no-top cages and uncaged plots (Table 6). These infaunal densities are similar to those measured in untreated areas in the subestuary during the same time period (Hines et al. 1987a). Mean densities of epibenthic predators caught in the drop net adjacent to the experimental plots (Table 6) were similar to those estimated from trawling data (see 'Population dynamics' above for densities adjusted for trawl catch efficiencies), except that Trinectes maculatus was not caught in the drop net.

Deployment of the experiment disturbed the sand plots very little, but bioturbation of the dyed sand was evident after 2 wk (Fig. 12). Inspection of the photographs indicated that insertion of the cores occasionally caused minor artifacts by dragging dyed sand deeper along the pipes, but dispersal of the dyed sand deeper into the sediment appeared to be caused primarily by burrowing infaunal organisms and by digging activities of crabs to depths of nearly $10 \mathrm{~cm}$. Almost no dyed sand was observed deeper than $10 \mathrm{~cm}$ in the cores. The distribution of the sand differed significantly among the treatments (Fig. 13; Kolmogorov-Smirnov tests, $\mathrm{p}<0.01$ ). Sand in the full-cage treatment was the least

Table 6. Densities of infauna in bioturbation experimental plots, and of epifaunal predators and other species of fish caught by drop net adjacent to bioturbation experimental site in Rhode River subestuary

\begin{tabular}{|lclc|}
\hline Infauna & $\begin{array}{c}\text { Density } \\
\left(\overline{\mathrm{X}} \pm \mathrm{SE} \mathrm{\textrm {m } ^ { - 2 }}\right)\end{array}$ & Epifaunal predators and others & $\begin{array}{c}\text { Density } \\
\left(\overline{\mathrm{X}} \pm \mathrm{SE} \mathrm{m} \mathrm{m}^{-2}\right)\end{array}$ \\
\hline Macoma balthica & $146 \pm 130$ & Callinectes sapidus & $0.08 \pm 0.02$ \\
Macoma mitchelli & $90+123$ & Leiostomus xanthurus & $0.01 \pm 0.008$ \\
Mya arenaria & $71+111$ & Micropogonias undulatus & $0.05 \pm 0.03$ \\
Mulinia lateralis & $7+13$ & Palaemonetes pugio & $0.7 \pm 0.2$ \\
Heteromastus filiformis & $302+148$ & Brevoortia tyrannus & $1.2 \pm 1.2$ \\
Nereis succinea & $158+141$ & Anchoa mitchilli & $0.3 \pm 0.1$ \\
Scolecolepides viridis & $69 \pm 112$ & Menidia menidia & $0.02 \pm 0.02$ \\
Tubificoides spp. & $51 \pm 104$ & Sygnathus fuscus & $0.01 \pm 0.01$ \\
Cyathura polita & $376 \pm 138$ & Cynoscion regalis & $0.01 \pm 0.01$ \\
Total organisms & $1273 \pm 209$ & & \\
\hline
\end{tabular}




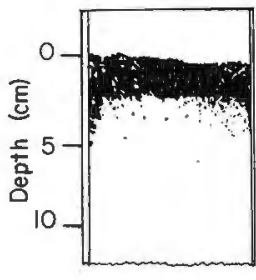

Time 0

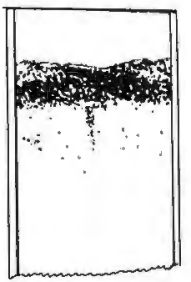

Full Cage

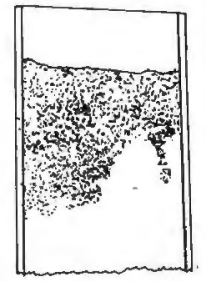

Two Sided

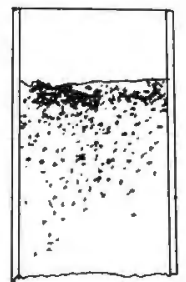

No Top

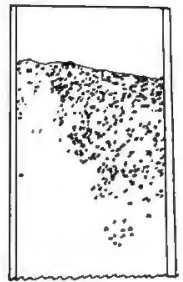

No Coge
Fig. 12. Bioturbation of sediments in Rhode River subestuary, Vertical profiles traced from representative photographs show sections through patches of dyed sand placed on sediment surface late August ('Time 0') and subjected to 4 cage treatments for $2 \mathrm{wk}$. Crabs and fish were excluded (full cage) or allowed access to patches in partial cages

(2-sided and no top) and uncaged areas disturbed, but differed significantly in distribution from the initial, 'Time 0' samples; sand in the uncaged and no-top treatments was most disturbed and did not differ significantly from each other in their distributions; while sand in the 2-sided cages was disturbed to an intermediate degree (Fig. 13; Kolmogorov-Sminnov tests, $\mathrm{p}<0.05$ ).

\section{DISCUSSION}

Predation by the guild of epibenthic fish and blue crabs clearly plays a major role in structuring infaunal communities in the Rhode River subestuary, as it does in higher salinity portions of Chesapeake Bay (Virnstein 1977, Holland et al. 1980, Orth et al. 1984) and in other marine soft-bottom communities (Peterson 1979, Woodin 1983, Dayton 1984). Predation intensity depends on the components of guild structure: temporal and spatial variability in species composition, species abundances, and size structure (Menge 1983). The functional role of predatory fish and crabs also depends both on variation in the guild's direct utiliza-

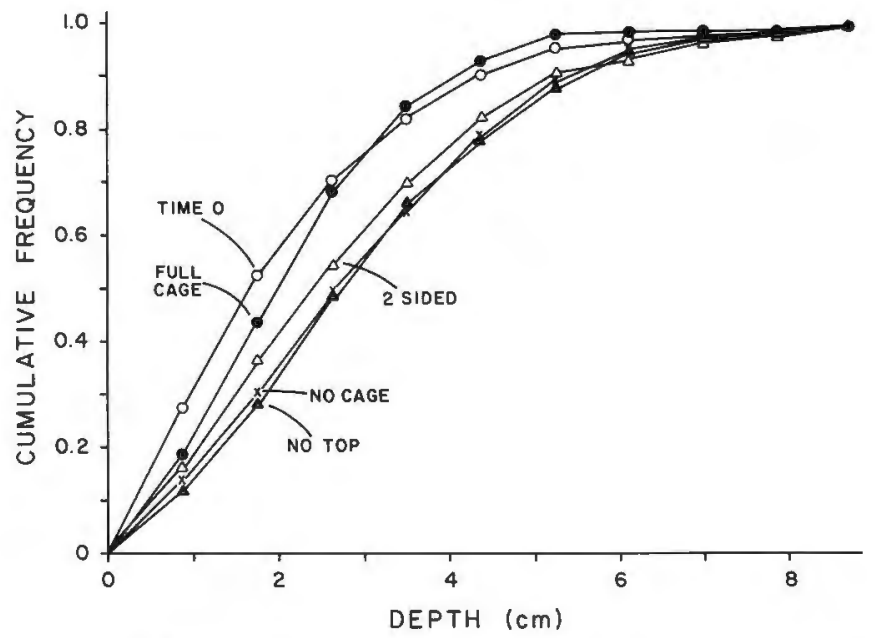

Fig. 13. Bioturbation of sediments in Rhode River subestuary. Average cummulative frequency distributions of dyed sand placed on experimental plots treated for $2 \mathrm{wk}$ with full, partial, and no predator exclusion cages. Only the no-top and no-cage treatments did not differ significantly from each other (Kolmogorov-Smirnov tests, $\mathrm{p}=0.05$ ) tion of prey resources (i.e. the predators' diets) and on indirect effects of the guild's foraging activities, such as bioturbation of sediments in the Rhode River. Our measures of long-term variation in guild structure, patterns of prey utilization, and field exclusion experiments allow assessment of the interaction of guild structure and function.

Structure of the guild of epibethnhic fish and crabs in the Rhode River subestuary exhibited marked temporal variability in the 1980's similar to the seasonal and annual fluctuations of the epibenthic fish in the central portion of Chesapeake Bay during the 1970's (Horwitz 1987). Almost paradoxically, however, the guild also exhibited several attributes of seasonal and long-term consistency similar to the temporally conservative cycles of fish in seagrass communities of the Gulf of Mexico (Livingston 1984). Although more than 3 dozen species were caught in trawls over the $8 \mathrm{yr}$ sampling period, a sciaenid usually Leiostomus xanthurus, occasionally Micropogonias undulatus, a sole Trinectes maculatus, and Callinectes sapidus were the numerically dominant members of the epibenthic predatory guild every year. Rank order of the species was significantly consistent over the study period; but the abundances of the dominant members of the guild fluctuated widely among years, especially in one year (1983) when $L$. xanthurus was absent and when the usually rare $M$. undulatus became common. Population abundances of the guild members underwent predictable seasonal cycles with peak abundances in summer and essentially no activity in winter, with consistent recruitment periods, and with similar monthly shifts in population structure among years. Yet abundances of each component species also fluctuated significantly, often several fold, among years. The 1983 increase of $M$. undulatus in the subestuary appears to have resulted from an unusual overwintering of juveniles in upper Chesapeake Bay (Horwitz 1987), but there is no apparent explanation for the concomitant absence of $L$. xanthurus. High densities of blue crabs in 1984 and 1985 appear to have resulted from a major peak in recruitment in 1984 in lower Chesapeake Bay, and that cohort persisted in high densities in our study area for the 2 yr life span of blue crabs. Thus, for blue crabs and sciaenids, which spawn in the ocean hundreds of 
kilometers from our study site, annual variation in predator abundance is regulated on a regional scale that has major impacts on the local scale of subestuaries.

Locally within the Rhode River, densities of the common epibenthic predators exhibited significant spatial variation on a scale of hundreds to thousands of meters during the summer foraging period. Although the sampling intensity in our study was not designed to provide fine resolution or mechanistic explanations of the guild's spatial variation, interspecific differences in aggregative behavior and resource utilization are probably major causes of the patchiness in predator distribution. Callinectes sapidus in the Rhode River partition the habitat by size, sex, and molt stage (Hines et al. 1987b). Leiostomus xanthurus and Micropogonias undulatus typically aggregate in schooling behavior, Trinectes maculatus is a solitary 'ambush' predator, and C. sapidus is cannibalistic. These intraspecific behavioral interactions themselves create differences in the patchiness of predators. Aggregative responses of predators (sensu Hassell 1978) to patchiness in prey distribution can also account for spatial variation in abundances of these fish and crabs, since infaunal densities vary significantly in the same spatial scale as the predators (Hines et al. 1987a, b).

The size structure of populations in the guild reflected the longevity and seasonal patterns of recruitment for the component species: a single year-class recruiting in spring (Leiostomus xanthurus) or fall (Micropogonias undulatus) for the sciaenids, 2 yearclasses with fall-spring movement into the subestuary for blue crabs, and 3 year-classes with fall recruitment for Trinectes maculatus. These population structures are similar to those of the same species in the middle portion of Chesapeake Bay (Horwitz 1987). The consistent seasonal pattern of rapid growth during the summer foraging season resulted in a consistent size range of most individuals each year: $L$. xanthurus $=40$ to $150 \mathrm{~mm}, M$. undulatus $=50$ to $200 \mathrm{~mm}, T$. maculatus $=$ 40 to $150 \mathrm{~mm}$, and Callinectes sapidus $=60$ to $170 \mathrm{~mm}$. Seasonal changes in size structure can have trophic consequences in some communities through ontogenetic transitions in diet (Livingston 1980, Werner \& Gilliam 1984). However, despite marked growth of juveniles over the foraging season, ontogenetic shifts in feeding habits of these species occur primarily at sizes smaller than these ranges. Small $L$, xanthurus and $M$. undulatus switch from feeding predominantly on meiofauna to macrofauna at ca $50 \mathrm{~mm}$ (Livingston 1980, O'Neil \& Weinstein 1987, Smith \& Coull 1987); $T$. maculatus switches to a macrofaunal diet at about $30 \mathrm{~mm}$ (Hines pers. obs.); and juvenile blue crabs shift to an adult diet composition at ca $60 \mathrm{~mm}$ (Laughlin 1982). Moreover, with the partial exception of small $L$. xanthurus consuming some meiofauna early in the season, our analysis of the predators' stomach contents showed that these sizes were clearly feeding predominantly on macro-infauna.

Diets of the epibenthic predators in the Rhode River subestuary were similar to stomach contents of these species in other locations (Carr \& Adams 1973, Chao \& Musick 1977, Homer \& Boyton 1979, Laughlin 1982, Livingston 1984, Smith \& Coull 1987). Our analysis of diet breadth and overlap provide a quantitative assessment of prey specialization for each species, and they quantified the extent of prey resource partitioning by the guild. Over the course of the summer season, the diets of each of the guild members are rather generalized, with each predator feeding on a wide variety of benthic species. However, for any given population sample their diets tended to be specialized, or relatively concentrated on particular prey categories, resulting in both resource partitioning and considerable overlap among species. Blue crabs clearly preyed extensively on clams, but also were opportunistic and cannibalistic. All 3 fish species consumed an array of worms and small crustaceans, especially amphipods; yet particular samples often had narrow dietary breadth. The fish did not prey upon whole clams, rather Leiostomus xanthurus and Trinectes maculatus nipped large numbers of Macoma balthica siphons, especially later in the season.

Because the major ontogenetic shifts in diet of the predators occur at sizes smaller than those predominant in the Rhode River (see above), seasonal shifts in prey resource utilization primarily reflected changes in prey availability (Holbrook \& Schmitt 1984, Pyke 1984, Schmitt \& Holbrook 1986). Infaunal prey abundance was high early in the season (June), with large numbers of small polychaetes, peracarids, and clams near the sediment surface; but prey abundance declined markedly by late season (August/September), with only deep burrowing large clams persisting (Hines \& Comtois 1985, Hines et al. 1987a). Seasonal shifts in the diet of large blue crabs in the subestuary were reflected in decreased dietary breadth and overlap as crabs specialized more on clams and took less small prey during the late period of low infaunal densities. However, as the fish apparently tracked the seasonally abundant small surface prey, their breadths remained relatively constant and dietary overlap among species was high throughout the season, indicating persistent feeding generalization despite diminished resources. None of the predator species showed qualitative differences in diet between the 2 sediment types, probably because infaunal species composition was quite similar in both muddy and sandy habitats within the subestuary (Hines \& Comtois 1985), and because the high mobility of these predators probably results in their 
frequent movement across both sediment types during feeding.

From analysis of the predator's diets, blue crabs were a primary source of mortality for clams, so that changes in blue crab density affected clam population levels. Although covariation of predator-prey cycles was complicated by large annual fluctuations in prey recruitment, both the seasonal and annual variations in predator and prey abundances provide insight into their population stability. Summer declines in newly recruited Macoma balthica coincided each year with the influx of blue crabs. Two apparently stable prey levels were superimposed upon the relatively regular seasonal cycles. Low clam recruitment and low crab abundance were correlated with a lower level of prey abundance. A major increase in clam recruitment with continued low crab abundance elevated the level of prey populations. In turn, the major 2 year influx of the 1984 cohort of crabs was followed by a return to the lower prey population level, which was again maintained by low clam recruitment and low crab abundance. Thus, prey populations appear to be regulated through interactions of both predator abundance and prey recruitment. Because the regulation is densitydependent for both predator and prey, experimental analysis of numerical and functional responses is likely to provide mechanistic explanations of the interaction, as well as spatial variation in predator and prey abundances (Holling 1959, Abrams 1987). Indeed, Lipcius \& Hines (1986) showed experimentally that shifts in the functional response of blue crabs foraging on Mya arenaria could account for local extinction or persistence of clam populations.

Predation by the guild of epibenthic predators clearly has strong (sensu Paine 1980) negative effects on infauna throughout the Rhode River subestuary, because excluding the predators prevented the usual summer decline of infaunal abundances. From stomach content analysis, many of these strong interactions are direct results of predation. The response to altered predation intensity was generally graded and dependent on predator density, as indicated by usually intermediate infaunal densities in partial exclusion cage treatments. The predator exclusion experiment also revealed significant spatial variation in the impact of the epibenthic guild, with the variation being a product of patchy distributions in both the predators and infaunal. Although the effect of predator exclusion was generally consistent among treatments at all stations, the magnitude of difference among treatments fluctuated among stations, probably reflecting spatial variation in the predators. Similarly, the abundances of infauna within the full cage treatment varied significantly among stations, reflecting patchy prey abundances independent of predators. Even species like
Macoma balthica which did not show a consistent pattern of response to predator exclusion treatments probably are strongly impacted by predation. Small-scale dispersal of these species away from higher density patches within the cages probably introduced an artifact into the experiment, since subsequent retention (by buckets) of these prey within cage refuges resulted in greatly increased clam survivorship.

In addition to direct consumption of prey, foraging activity of the predators causes major disturbance of the estuarine sediment. This disturbance may be particularly pronounced in the low salinity, upper reaches of estuaries like the Rhode River, which have relatively few subsurface deposit feeders compared to lower portions of estuaries, where bioturbation by infaunal 'conveyer belt' subsurface deposit feeders is probably high (Gaston \& Nasci 1988). In other soft-bottom communities, rays and horseshoe crabs are major agents of disturbance impacting infaunal communities (Woodin 1981, Van Blaricom 1982). In the Rhode River, fish probably impact only the upper 2 to $3 \mathrm{~cm}$ of sediment, while blue crabs foraging on clams are the main species capable of sedimentary disturbance to the $10 \mathrm{~cm}$ depth indicated by our bioturbation experiment (Blundon \& Kennedy 1982, Hines \& Comtois 1985).

In soft-bottom ecosystems like the Rhode River subestuary, predator-prey interactions are particularly complex (sensu Carpenter \& Kitchell 1988) because these communities are dominated by guilds of rather generalized predators capable of switching among diverse prey, and because they usually lack a single competitively dominant prey species capable of monopolizing resources (Reise 1978, Virnstein 1980, Kneib \& Stiven 1982, Ambrose 1984, Commito \& Ambrose 1985). That is, while predation is often the prevailing control of community structure, a single keystone-like species occurs rarely if at all (Peterson 1979, Levinton 1982). In the Rhode River, the consistent seasonal influx of predators produces intense predation pressure that greatly reduces infaunal abundances each summer. Because the 4 dominant members of the guild are generalized, mobile predators with overlapping diets, the direct impact of predation and disturbance is strong for the entire infaunal community.

Our analysis also indicates that variation in the structure of the predatory guild produces an array of significant indirect consequences for the infaunal community. First, variation in abundance of blue crabs has major consequences for infaunal community structure as a result of both direct and indirect effects of crab predation on clams. Clams comprise the bulk of the biomass in the infaunal community (Hines \& Comtois 1985) and have density-dependent effects on infaunal community structure (Hines et al. 1989). Second, predator stomach contents indicate that variation in abundance of fish 
in the guild will affect the intensity of clam siphon nipping. The extensive cropping of Macoma balthica siphons by the fish is likely to have a significant indirect effect on clam survival by causing the clams to reside at shallower sedimentary depths, where they are more vulnerable to predation by blue crabs (Reading \& McGrorty 1978, Zwarts 1986, Zwarts \& Wanink 1989, Hines \& Lipcius unpubl.). Third, as consumers of infaunal predatory worms, variation in the abundance of fish in the guild alters the ratio of infaunal predators to infaunal prey. Although the validity of these altered ratios is open to question (see Ambrose 1984, 1986, Wilson 1986), the shifts in ratios that we observed in the predator exclusion experiment indicate that nonlinear effects on community structure occur with variation in fish predation intensity. In areas of inherently low diversity like the upper reaches of estuaries, these shifts in species composition may be of considerable consequence. Fourth, variation in abundance and species composition of the predatory guild will affect the intensity and sedimentary depth of bioturbation, with crabs having impacts to $10 \mathrm{~cm}$ but the fish affecting only the surface. The bioturbation of sediments by the predator guild will have indirect effects on infaunal community structure, because sedimentary destabilization is well-known to have differential species effects favoring deposit feeders at the expense of suspension feeders (Rhoads 1974, Woodin 1976, 1983, Thayer 1983). Therefore, variation in structure of the predatory guild has many strong indirect effects on the benthic community.

Our descriptive and experimental data thus indicate that the guild's foraging activity not only has strong direct effects on infaunal community structure, but spatial and temporal variability in the guild structure produces major complex interactions for benthic community organization and patch dynamics. The consistent seasonal influx of generalized mobile predators produces a strong direct impact of predation and disturbance for the entire infaunal community despite annual variation in component species. However, effects of predator functional and numerical responses, which define predator-prey interactions, are highly sensitive to low prey densities (Holling 1959, Hassell 1978, Lipcius \& Hines 1986, Abrams 1987); so spatial and temporal variation in the predatory guild and infaunal prey have marked effects on patterns of prey survival each summer. The patterns of prey survival are complicated by the large number of indirect effects of predator switching and bioturbation, but our descriptive and experimental analysis of these interactions has produced a more realistic assessment of their complexities.

\section{Appendix 1}

Summary means for stomach content analysis for guild of epibenthic predators (1981 to 1988). UP: unidentified polychaetes, DAT: digested animal tissue. No data for $M$. undulatus in September

\begin{tabular}{|c|c|c|c|c|c|c|c|c|c|c|c|c|c|c|c|}
\hline & \multicolumn{4}{|c|}{ Callinectes sapidus } & \multicolumn{4}{|c|}{ Leiostomus xanthurus } & \multicolumn{3}{|c|}{ Micropogonias undulatus } & \multicolumn{4}{|c|}{ Trinectes maculatus } \\
\hline & Mud & Sand & Mud & Sand & Mud & Sand & Mud & Sand & Mud & Sand & September & Mud & Sand & Mud & Sand \\
\hline $\mathrm{N}$ & 63 & 57 & 80 & 92 & 19 & 39 & 64 & 65 & 20 & 20 & & 120 & 235 & 169 & 169 \\
\hline Size (mm) & 125 & 124 & 133 & 133 & 68 & 84 & 118 & 124 & 112 & 119 & & 58 & 56 & 81 & 84 \\
\hline Stomach fullness (\%) & 38 & 32 & 35 & 26 & 13 & 38 & 48 & 37 & 53 & 45 & & 45 & 41 & 33 & 32 \\
\hline Contents dry weight (mg) & 379 & 227 & 324 & 204 & 3.44 & 9.64 & 29.5 & 42.1 & 14.5 & 12.4 & & 2.08 & 1.79 & 4.11 & 3.97 \\
\hline Fish & 10 & 17 & 17 & 4 & 0 & 0 & 0 & 0 & 0 & 0 & & 0 & 0 & 0 & 0 \\
\hline Clams & 29 & 37 & 52 & 56 & 0 & 0 & 2 & 5 & 0 & 0 & & 0 & 0 & 0 & 0 \\
\hline Macoma balthica siphons & 0 & 0 & 0 & 0 & 3 & 2 & 48 & 35 & 0 & 0 & & 11 & 19 & 22 & 23 \\
\hline Copepods & 0 & 0 & 0 & 0 & 19 & 9 & 2 & 1 & 0 & 0 & & 0 & 0 & 0 & 0 \\
\hline Nematodes & 0 & 0 & 0 & 0 & 19 & 2 & 2 & 2 & 0 & 0 & & 0 & 0 & 0 & 0 \\
\hline Mysids & 4 & 0 & 0 & 0 & 0 & 0 & 1 & 2 & 0 & 0 & & 0 & 0 & 0 & 0 \\
\hline Heteromastus filiformis & 0 & 0 & 0 & 0 & 5 & 1 & 8 & 14 & 0 & 0 & & 6 & 6 & 3 & 6 \\
\hline Eteone heteropoda & 0 & 0 & 0 & 0 & 0 & 3 & 0 & 2 & 0 & 0 & & 2 & 2 & 4 & 3 \\
\hline Nereis succinea & 2 & 6 & 0 & 0 & 0 & 1 & 10 & 8 & 7 & 1 & & 1 & 2 & 8 & 11 \\
\hline Scolecolepides viridis & 0 & 0 & 0 & 0 & 0 & 0 & 0 & 0 & 0 & 0 & & 4 & 1 & 12 & 9 \\
\hline UP & 0 & 0 & 0 & 0 & 0 & 0 & 0 & 1 & 0 & 0 & & 0 & 3 & 8 & 5 \\
\hline DAT & 20 & 9 & 20 & 21 & 5 & 6 & 4 & 6 & 9 & 11 & & 4 & 6 & 5 & 2 \\
\hline Detritus & 2 & 1 & 0 & 2 & 17 & 14 & 15 & 11 & 8 & 20 & & 0 & 0 & 0 & 1 \\
\hline Sediment & 0 & 2 & 1 & 5 & 0 & 0 & 0 & 0 & 5 & 12 & & 0 & 0 & 0 & 0 \\
\hline
\end{tabular}


Acknowledgements. We thank Kathy Paige and Cynthia Trowbridge for their patience in analyzing stomach contents of blue crabs, spot and hogchokers. Kathy Paige and Patty Haddon assisted with the predator exclusion and bioturbation experiments. Craig Kelly provided technical help with the bioturbation experiment. Kathy Paige, Patty Haddon, Gina Tritaik, Debbie Palmer, David Smith, and a multitude of Work Learn Interns, postdoctoral fellows and volunteers cheerfully provided the labor to sustain the long-term trawling program. Comments by Martin Posey, Joe Dineen, Bob Orth, Greg Ruiz, L. David Smith, and two reviewers improved early drafts of the manuscript. This research was supported in part by grants from the Smithsonian Environmental Sciences Program, the Smithsonian Scholarly Studies Program, the National Science Foundation (Grant No. OCE-8700414), and Maryland Department of Natural Resources.

\section{LITERATURE CITED}

Abrams, P. (1987). Indirect interactions between species that share a predator: varieties of indirect effects. In: Kerfoot, W., Sih, A. (eds.) Predation: direct and indirect impacts on aquatic communities. University Press of New England, Hanover, New Hampshire, p. 38-54

Ambrose, W. G. (1984). Role of predatory infauna in structuring marine soft-bottom communities. Mar. Ecol. Prog. Ser. 17: $109-115$

Ambrose, W. G. (1986). Importance of predatory infauna in marine soft-bottom communities: reply to Wilson. Mar. Ecol. Prog. Ser. 32: 41-45

Baird, D., Ulanowicz, R. E. (1989). The seasonal dynamics of the Chesapeake Bay ecosystem. Ecol. Monogr. 59: 329-361

Bertness, M. D., Garritz, S. D., Levings, S. C. (1981). Predation pressure and gastropod foraging: a tropical-temperate comparison. Evolution 35: 995-1007

Blundon, J. A., Kennedy, V. S. (1982). Refuges for infaunal bivalves from blue crab Callinectes sapidus (Rathbun) predation in Chesapeake Bay. J. exp. mar. Biol. Ecol. 65: $67-81$

Boesch, D. F. (1977). A new look at the zonation of benthos along the estuarine gradient. In: Coull, B. C. (ed.) Ecology of marine benthos. Belle W. Baruch Library in Mar. Sci., Vol. 6. University of South Carolina Press, Columbia, South Carolina, p. 245-266

Brenchley, G. A. (1981). Disturbance and community structure: an experimental study of bioturbation in marine softbottom communities. J. mar. Res. 39: 767-790

Carr, W. E. S., Adams, C. A. (1973). Food habits of juvenile marine fishes occupying seagrass beds in the estuarine zone near Crystal River, Florida. Trans. Am. Fish. Soc. 102: $511-540$

Carpenter, S., Kitchell, J. (1988). Introduction. In: Carpenter, S. (ed.) Complex interactions in lake communities. Springer-Verlag, New York, p. 1-8

Chao, L. N., Musick, J. A. (1977). Life history, feeding habits, and functional morphology of juvenile sciaenid fishes in the York River estuary, Virginia. Fish. Bull. U.S. 75: $657-702$

Cicchetti, D. V. (1972). Extension of multiple-range tests to interaction tables in the analysis of variance: a rapid approximate solution. Psychological Bull. 77: 405-408

Cody, M. L. (1974). Competition and the structure of bird communities. Princeton Univ. Press, Princeton

Colwell, R. K., Futuyma, D. J. (1971). On the measurement of niche breadth and overlap. Ecology 52: 567-576
Commito, J. A., Ambrose, W. G. (1985). Multiple trophic levels in soft-bottom communities. Mar. Ecol. Prog. Ser. 26: 289-293

Correll, D. C. (1978). Estuarine productivity. BioSci. 28: 645-650

Cory, R. L., Dresler, P. V. (1981). Diel oxygen variations in the Rhode River estuary, Maryland, 1970-1978. U.S. Geological Survey, Water Resources Investigations, 81-10, Reston, Virginia

Day, R. W., Quinn, G. P. (1989). Comparisons of treatments after an analysis of variance in ecology. Ecol. Monogr. 59: 467-468

Dayton, P. K. (1984). Processes structuring some marine communities: are they general? In: Strong, D., Simberloff, D., Abele, L., Thistle, A. (eds.) Ecological communities: conceptual issues and the evidence. Princeton Univ. Press, Princeton, p. 181-197

Gaston, G. R., Nasci, J. C. (1988). Trophic structure of macrobenthic communities in the Calcasieu estuary, Louisiana. Estuaries 11: 201-211

Gilmore, R. G., Holt, J., Jones, R. S., Kulczycki, G. R., McDowell, L. G., Magley, W. C. (1978). Portable tripod dropnet for estuarine fish studies. Fish. Bull. U.S. 76: 285-289

Hassell, M. (1978). The dynamics of arthropod predator-prey systems. Monographs in population biology 13. Princeton Univ. Press, Princeton

Heck, K. L., Wilson, K. A. (1987). Predation rates on decapod crustaceans in latitudinally separated seagrass communities: a study of spatial and temporal variation using tethering techniques. J. exp. mar. Biol. Ecol. 107: 87-100

Hines, A. H. (1982). Coexistence in a kelp forest: size, population dynamics, and resource partitioning in a guild of spider crabs (Brachyura, Majidae). Ecol. Monogr. 52: 179-198

Hines, A. H., Comtois, K. L. (1985). Vertical distribution of infauna in sediments of a subestuary of central Chesapeake Bay. Estuaries 8: 296-304

Hines, A. H., Haddon, P. J., Miklas, J. J., Wiechert, L. A., Haddon, A. M. (1987a). Estuarine invertebrates and fish: sampling design and constraints for long-term measurements of population dynamics. In: Boyle, T. P. (ed.) New approaches to monitoring aquatic ecosystems. ASTM STP 940. Am. Soc. Testing and Materials, Philadelphia, Pennsylvania, p. 140-164

Hines, A. H., Lipcius, R. N., Haddon, A. M. (1987b). Population dynamics and habitat partitioning by size, sex, and molt stage of blue crabs Callinectes sapidus in a subestuary of central Chesapeake Bay. Mar. Ecol. Prog. Ser. 36: 55-64

Hines, A. H., Posey, M. H., Maddon, P. J. (1989). Effects of adult suspension- and deposit-feeding bivalves on recruitment of estuarine infauna. Veliger 32: 109-119

Holbrook, S. J., Schmitt, R. J. (1984). Experimental analysis of patch selection by foraging black surf perch (Embiotoca jacksoni). J. exp. mar. Biol. Ecol. 79: 39-64

Holland, A. F. (1985). Long-term variation of macrobenthos in a mesohaline region of Chesapeake Bay. Estuaries 8: 93-113

Holland, A. F., Mountford, N., Hiegal, M., Kaumeyer, K., Mihursky, J. (1980). Influence of predation on infaunal abundance in upper Chesapeake Bay, USA. Mar. Biol. 57: 221-235

Holling, C. (1959). The components of predation as revealed by a study of small mammal predation of the European pine sawfly. Can. J. Entomol. 91:293-320

Homer, M., Boyton, W. R. (1979). Stomach analysis of fish collected in the Calvert Cliffs region, Chesapeake Bay - 
1977. Final Contract Report, MD Dept. of Natural Resources, Power Plant Siting Program, Nos. P2-72-02(77) and P2-72-02(78), Tawes State Office BIdg., Annapolis, Maryland

Homer, M., Mihursky, J. A., Jones, P. (1980). Quantitative approaches towards characterizing estuarine fish populations and communities. Proc. 4th Ann. Meet. Potomac Chapter, Am. Fish. Soc., Washington, D.C., p. 39-99

Horwitz, R. J. (1987). Fish. In: Heck, K. L. (ed.) Ecological studies in the middle reach of Chesapeake Bay, Calvert Cliffs, vol. 23. Lecture notes on coastal and estuarine studies. Springer-Verlag, New York, p. 167-225

Jeffries, H. P., Terceiro, M. (1985). Cycle of changing abundances in the fishes of the Narragansett Bay area. Mar. Ecol. Prog. Ser. 25: 239-244

Kjelson, M. A., Johnson, G. W. (1978). Catch efficiencies of a 6.1-meter trawl for estuarine fish populations. Trans. Am. Fish. Soc. 107: 246-354

Kneib, R. T., Stiven, A. E. (1982). Benthic invertebrate responses to size and density manipulations of the common mummichog, Fundulus heteroclitus, in an intertidal salt marsh. Ecology 63: 1518-1532

Laughlin, R. (1982). Feeding habits of the blue crab, Callinectes sapidus Rathbun, in the Apalachicola estuary, Florida. Bull. mar. Sci. 32: 807-822

Levinton, J. S. (1982). Marine ecology. Prentice-Hall, Englewood Cliffs

Lipcius, R. N., Hines, A. H. (1986). Variable functional responses of a marine predator in dissimilar homogenous microhabitats. Ecology 67: 1361-1371

Livingston, R. J. (1980). Ontogenetic trophic relationships and stress in a coastal seagrass system in Florida. In: Kennedy, V. S. (ed.) Estuarine perspectives. Academic Press, New York, p. 423-435

Livingston, R. J. (1984). Trophic response of fishes to habitat variability in coastal seagrass systems. Ecology 65: 1258-1275

Meeter, D. A., Livingston, R. J., Woodsum, G. C. (1979). Longterm climatogical cycles and population changes in a riverdominated estuarine system. In: Livingston, R. J. (ed.) Ecological processes in coastal and marine systems. Plenum Press, New York, p. 315-338

Menge, B. A. (1978a). Predation intensity in a rocky intertidal community. Relation between predator foraging activity and environmental harshness. Oecologia 34: 1-16

Menge, B. A. (1978b). Predation intensity in a rocky intertidal community. Effects of an algal canopy, wave action and desiccation on predator feeding rates. Oecologia 34: 17-35

Menge, B. (1983). Components of predation intensity in the low zone of the New England rocky intertidal region. Oecologia 58: 141-155

Menge, B. A., Lubchenko, J. (1981). Community organization in temperate and tropical rocky intertidal habitats: prey refuges in relation to consumer pressure gradients. Ecol. Monogr. 51: 429-450

Menge, B. A., Sutherland, J. (1976). Species diversity gradients: synthesis of the roles of predation, competition, and temporal heterogeneity. Am. Nat. 110: 351-369

O'Neil, S. P., Weinstein, M. P. (1987). Feeding habits of spot, Leiostomus xanthurus, in polyhaline versus mesohaline tidal creeks and shoals. Fish. Bull. U.S. 85: 785-796

Orth, R. J., Heck, K. L., Van Montfrans, J. (1984). Faunal communities in seagrass beds: A review of the influence of plant structure and prey characteristics on predator-prey relationships. Estuaries 7: 339-350

Paine, R. T. (1966). Food web complexity and species diversity. Am. Nat. 100: 68-75
Paine, R. T. (1980). Food webs: linkage, interaction strength, and community infrastructure. J. Anim. Ecol. 49: 667-685

Peterson, C. H. (1979). Predation, competitive exclusion, and diversity in the soft-sediment benthic communities of estuaries and lagoons. In: Livingston, R. J. (ed.) Ecological processes in coastal and marine systems. Plenum Press, New York, p. 233-264

Posey, M. H. (1987). Influence of relative mobilities on the composition of benthic communities. Mar. Ecol. Prog. Ser. 39: 99-104

Pyke, G. H. (1984). Optimal foraging theory: a critical review. A. Rev. Ecol. Syst. 15: 523-571

Quammen, M. (1984). Predation by shorebirds, fish, and crabs on invertebrates in intertidal mudflats: an experimental test. Ecology 65: 529-537

Reading, C. J., McGrorty, S. (1978). Seasonal variations in the burying depth of Macoma balthica (L.) and its accessibility to wading birds. Estuar, coast. mar. Sci. 6: 135-144

Reise, K. (1978). Experiments on epibenthic predation in the Wadden Sea. Helgoländer wiss. Meeresunters. 31: 55-101

Rhoads, D. C. (1974). Organism-sediment relations on the muddy sea floor. Oceanogr. Mar. Biol. A. Rev. 12: 263-300

Rhoads, D. C., Young, D. K. (1971). Animal-sediment relations in Cape Cod Bay, Massachusetts. I. Reworking by Molpadia oolitica (Holothuroidea). Mar. Biol. 11: 255-261

Root, R. B. (1967). The niche exploitation pattern of the bluegrey gnatcatcher. Ecol. Monogr. 37: 317-350

SAS Institute, Inc. (1988). SAS user's guide: statistics. Cary, North Carolina

Schmitt, R. J., Holbrook, S. J. (1986). Seasonally fluctuating resources and temporal variability of interspecific competition. Oecologia 69: 1-11

Smith, L. D., Coull, B. C. (1987). Juvenile spot (Pisces) and grass shrimp predation on meiobenthos in muddy and sandy substrates. J. exp. mar. Biol. Ecol. 105: 123-139

Sokal, R. R., Rohlf, F. J. (1981). Biometry. The principles and practice of statistics in biological research, 2 nd edn. W. H. Freeman Co., New York

Thayer, C. W. (1983). Sediment-mediated biological disturbance and the evolution of marine benthos. In: Tevesz, M. J. S., McCall, P. L. (eds.) Biotic interactions in recent and fossil benthic communities. Plenum Press, New York, p. 479-625

Van Blaricom, G. R. (1982). Experimental analyses of structural regulation in a marine sand community exposed to oceanic swell. Ecol. Monogr. 52: 283-305

Virnstein, R. W. (1977). The importance of predation by crabs and fishes on benthic infauna in Chesapeake Bay. Ecology 58: 1199-1217

Virnstein, R. W. (1979). Predation on estuarine infauna: response patterns of component species. Estuaries 2: 69-86

Virnstein, R. W. (1980). Measuring effects of predation on benthic communities in soft sediments. In: Kennedy, V. S. (ed.) Estuarine perspectives. Academic Press, New York, p. 281-290

Werner, E. E., Gilliam, J. F. (1984). The ontogenetic niche and species interactions in size-structured populations. A. Rev. Ecol. Syst. 15: 393-425

Wilson, W. H. (1986). On the importance of predatory infauna in marine soft-bottom communities. Mar. Ecol. Prog. Ser. 32: $35-40$

Woodin, S. A. (1976). Adult-larval interactions in dense infaunal assemblages: patterns of abundance. J. mar. Res. 34: $25-41$

Woodin, S. A. (1981). Disturbance and community structure in a shallow water sand flat. Ecology 62: 1052-1066 
Woodin, S. A. (1983). Biotic interactions in recent marine sedimentary environments. In: Tevesz, M. J. J., McCall, P. L. (eds.) Biotic interactions in recent and fossil benthic communities. Plenum Press, New York, p. 3-38

Young, D. K. (1971). Effects of infauna on the sediment and seston of a subtidal environment. Vie Milieu (Suppl.) 22: 557-571

This article was submitted to the editor
Zwarts, L. (1986). Burying depth of the benthic bivalve Scrobicularia plana (da Costa) in relation to siphon-cropping. J. exp. mar. Biol. Ecol. 101: 25-39

Zwarts, L., Wanink, J. (1989). Siphon size and burying depth in deposit- and suspension-feeding benthic bivalves. Mar. Biol. 100: 227-240

Manuscript first received: June $16,1989^{-}$

Revised version accepted: July 12, 1990 